\title{
LEGITIMATE YET MANIPULATIVE: THE CONUNDRUM OF OPEN-MARKET MANIPULATION
}

\author{
GINA-GAIL S. FLETCHER $†$
}

\begin{abstract}
Is manipulation possible in the absence of misconduct? This is the foundational inquiry at the heart of open-market manipulation. Openmarket manipulation captures the attention of lawmakers and courts because it is market manipulation effected entirely through facially legitimate transactions. Whereas traditional, well-accepted forms of market manipulation involve deception, fraud, and monopolistic prices, open-market manipulation involves no objectively bad acts and, instead, is accomplished through permissible transactions executed on the open market. As enforcement of this form of manipulation increases, the question arises - when, if ever, is a legitimate transaction manipulative?

To the Securities Exchange Commission and the Commodity Futures Trading Commission ("the Commissions"), the answer is simple-legitimate transactions are manipulative if the trader intends to manipulate the market. The Commissions' enforcement actions are based on the theory that the manipulative intent of the trader is sufficient to transform otherwise legitimate transactions into openmarket manipulation. But this approach is fundamentally flawed. Traders may be treated differently for the same conduct under this approach, and it leaves market actors none the wiser as to when their conduct may be considered manipulative. Indeed, the Commissions' intent-focused approach only exacerbates the chaos that currently
\end{abstract}

Copyright @ 2018 Gina-Gail S. Fletcher.

$\dagger$ Associate Professor, Indiana University Maurer School of Law. J.D. Cornell Law School. B.A. Mount Holyoke College. For helpful comments, I would like to thank the participants of the Fifth Annual Workshop for Corporate \& Securities Litigation, the 2018 AALS Securities Section Junior Workshop, and the 2018 Culp Colloquium at Stanford Law School. I am also grateful for feedback from Jordan Barry, Kevin E. Davis, Gregory C. Edwards, Gizelle Fletcher, Joseph A. Grundfest, Joseph L. Hoffman, Michael Klausner, Therese H. Maynard, Ajay K. Mehrotra, Donna M. Nagy, Aviva A. Orenstein, Elizabeth Pollman, and Veronica Root. Sabienne Brutus, Lucrecia Guerra Galdamez, and Nia Yarborough provided invaluable research assistance. All errors and omission are my own. 
surrounds the law of market manipulation and makes enforcement against open-market manipulation less effective.

This Article is the first in-depth analysis of the concept of openmarket manipulation, and it finds the Commissions' approach to be sorely lacking. While the Commissions are correct to conclude that facially legitimate transactions may be manipulative, the intent-centric model is untenable. Intent is an insufficient tool in identifying openmarket manipulation because it does not address the most important aspect of open-market manipulation-how open-market transactions harm the markets. Thus, this Article argues that courts and regulators should, instead, coherently identify the necessary conditions under which open-market transactions are harmful to the markets. Specifically, this Article argues that only those open-market transactions that impede the markets' efficiency and undermine their integrity should be deemed manipulative. Linking the theory of openmarket manipulation to the purpose of anti-manipulation laws would provide the Commissions with more cogent principles on which to hold manipulators liable for their seemingly legitimate transactions.

\section{TABLE OF CONTENTS}

Introduction 481

I. A Primer on Market Manipulation................................................... 488

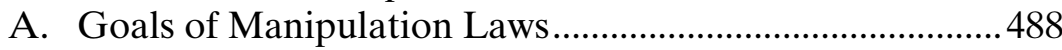

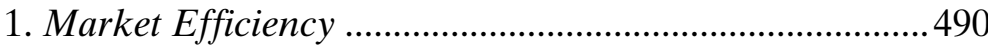

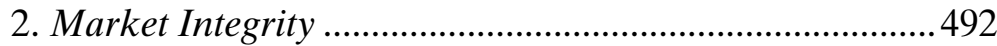

B. Defining Market Manipulation ............................................494

C. Anti-Manipulation Laws ……...............................................496

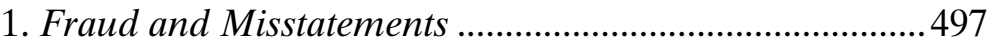

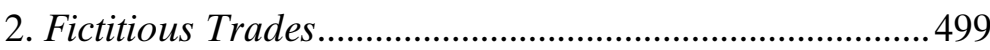

3. Price Manipulation ..........................................................50

II. Understanding Open-Market Manipulation....................................501

A. The Mechanics of Open-Market Manipulation ..................502

1. Typology: Naked and Covered Manipulation

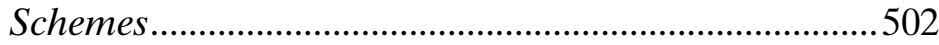

2. Common Strategies.............................................................505

B. Manipulating Openly: Case Studies ...................................508

1. Naked Price Control: Markowski v. SEC .......................509

2. Multiparty Scheme: United States v. Mulheren ..............510

3. Last-Minute Trading: SEC v. Masri .................................511

4. Guaranteed Profits: CFTC v. Amaranth Advisors ........513

C. The Insufficiency of Intent ................................................515 
1. Scope of intent. 515

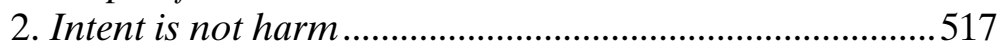

III. A Harm-Based Approach.................................................................519

A. Why Harm Matters ............................................................519

B. Identifying Harm to the Markets ......................................520

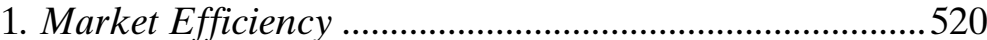

2. Market Integrity ....................................................................5 530

C. A Role for Market Discipline? .............................................535

D. Proposals for Reform.........................................................538

1. Adopt a Harm-Based Approach .....................................538

2. Amend the Price-Artificiality Standard ...........................539

3. Recognize Liability for Harming Market Integrity ........540

4. Implement Disclosure Obligations for Certain

Trading Strategies ................................................................542

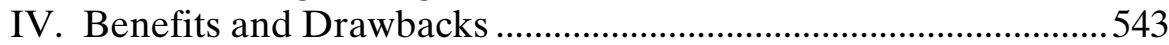

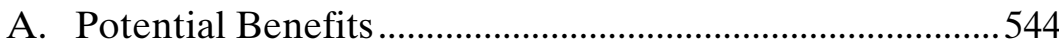

1. Reduced Transaction Costs.............................................544

2. Market Certainty and Regulatory Flexibility...................545

3. Private-Party Engagement ...............................................546

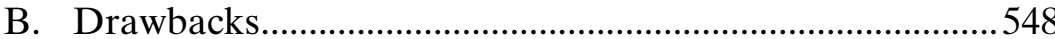

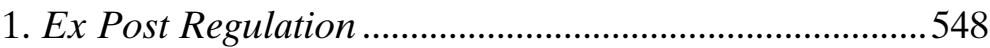

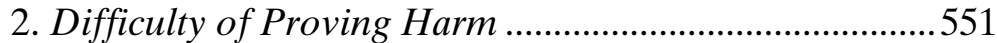

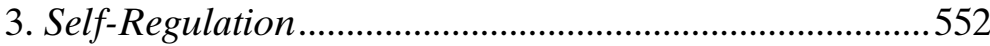

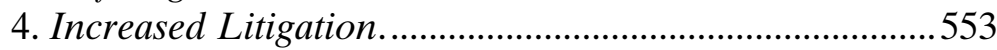

Conclusion.

\section{INTRODUCTION}

Manipulation is difficult to define .... [D]rawing a line between healthy economic behavior and that which is offensive has proved to be too subjective and imprecise to produce an effective regulatory tool. ${ }^{1}$

Traditionally, the notion of market manipulation triggers ideas of deliberate misconduct that allows unscrupulous actors to profit at the expense of others. Whether through false or misleading information or through market monopolization, market manipulation commonly evokes the image of a bad actor, oftentimes a speculator, who has purposefully attempted to "game the market" in ways that are injurious to the proper functioning of the markets. It is this expectation

1. Robert C. Lower, Disruptions of the Futures Market: A Comment on Dealing with Market Manipulation, 8 YALE J. ON REG. 391, 392 (1991). 
of manipulation that makes the allegations of market manipulation against Kraft Foods ("Kraft") most perplexing.

Kraft is one of the largest consumers of wheat, using it to produce many of its signature products-Oreos, Wheat Thins, Triscuit crackers, and Chips Ahoy! cookies. ${ }^{2}$ As a primary consumer of a classic physical commodity, Kraft represents the quintessential "good" actor in the commodities market. It is not a speculator, trading for pure profit; rather, it is an end user of wheat, and it utilizes the commodities markets to protect itself from price fluctuations and shortages that could significantly impact its business. Kraft is the type of market actor for which the futures markets exist - an entity that uses the markets to offset risk inherent to its business. Yet, in 2015, the Commodity Futures Trading Commission ("CFTC") accused Kraft of manipulating the wheat market. ${ }^{3}$

The allegations of manipulation arose from Kraft's trading strategy of taking advantage of a price discrepancy between the price for wheat on the futures market and the physical market. ${ }^{4}$ Futures are contracts that represent the right to buy or sell a commodity at a set price on an agreed-upon date. ${ }^{5}$ The price of futures contracts is connected to, but not necessarily the same as, the price of the asset on which they are based. ${ }^{6}$ Thus, the price of wheat futures is often affected by conditions in the physical market. In 2011, drought ruined worldwide wheat crops, and as a result, wheat on the physical market was at an all-time high. ${ }^{7}$ In response, Kraft purchased a six-month

2. CFTC v. Kraft Foods Grp., Inc., 153 F. Supp. 3d 996, 1002 (N.D. Ill. 2015) ("Kraft is one of the largest domestic users of \#2 Soft Red Winter Wheat . . . Kraft uses that wheat in the production of snack foods, including Oreo, Ritz, Triscuit, Wheat Thins, and Chips Ahoy!" (citation omitted)).

3. Id. at 1004 ("Plaintiff alleges that in October 2011, despite the results of its trial run, Kraft wheat procurement staff proposed to Kraft senior management a strategy of buying \$90 million of December 2011 wheat futures in order to depress the price of cash wheat and inflate the price of futures wheat." (citation omitted)).

4. The physical market is also known as the cash market.

5. See Gina-Gail S. Fletcher, Hazardous Hedging: The (Unacknowledged) Risks of Hedging with Credit Derivatives, 33 REV. OF BANKING \& FIN. L. 813, 826 (2014) [hereinafter Fletcher, Hazardous Hedging] (defining futures and other derivative instruments).

6. Scott H. Irwin \& Dwight R. Sanders, The Impact of Index and Swap Funds on Commodity Futures Markets 6-7 (OECD, Food, Agriculture and Fisheries Working Paper No. 27, 2010), http://www.oecd.org/trade/agricultural-trade/45534528.pdf [https://perma.cc/WX5HMNZD] (explaining that buyers of futures contracts are owners of the physical commodity, since their "long" position is matched by real inventory, and that they can create a "short" in the physical supply by holding their long position, increasing the price of the commodity).

7. Gary Vocke, Wheat Year in Review (Domestic): Higher Domestic Use and Exports Lower 2010/11 Ending Stocks, USDA ElEC. OUTLOOK REP. FROM THE ECON. RES. SERV. 1 (Jan. 2012), 
supply of wheat futures, which, at the time, was cheaper than physical wheat. ${ }^{8}$ The wheat connected to the futures was not of a high enough quality for Kraft to use in its manufacturing; nonetheless, Kraft's $\$ 90$ million purchase of wheat futures allegedly lowered the price of wheat on the cash market. ${ }^{9}$ With the price of physical wheat reduced, Kraft "netted out" its futures ${ }^{10}$ and avoided $\$ 5.4$ million in losses. ${ }^{11}$

Was Kraft's large purchase an act of manipulation or the conduct of a savvy end user seeking the best price? To the CFTC, Kraft was guilty of market manipulation because it purchased wheat futures with the intent to manipulate the physical price of wheat downwards. ${ }^{12}$ Interestingly, Kraft's strategy did not involve illegal transactions or behavior typically associated with market manipulation. The CFTC did not allege that Kraft "cornered" the market; ${ }^{13}$ nor did it allege that the

http://usda.mannlib.cornell.edu/usda/ers/WHS//2010s/2012/WHS-01-24-2012.pdf [https:// perma.cc/DRE4-DVSM] ("The all-wheat season-average price (SAP) for 2010/11 was $\$ 5.70$ per bushel. This price was above ... SAP for the preceding marketing year of $\$ 4.87$, but less than the all-time record $\$ 6.78$ in 2008/09 and . . p previous record of $\$ 6.48$ in 2007/08. The 2010/11 price was higher than all years ... [before] 2007/08.”); Lester R. Brown, The Great Food Crisis of 2011, EARTH POL'Y INST. (Jan. 14, 2011), http://www.earth-policy.org/mobile/releases/update90 [https://perma.cc/C2J8-PFZD] ("As the new year begins, the price of wheat is setting an all-time high in the United Kingdom."); Wheat, TRADING ECONS., https://tradingeconomics.com/ commodity/wheat [https://perma.cc/3MZV-8KYC] ("Historically, Wheat reached an all time high of 1194.50 in February of 2008 and a record low of 192 in July of 1999."); Wheat Prices Reaches All Time High!, LEVERAGE ACAD. F. (Jan. 27, 2011, 9:41 PM), http://leverageacademy.com/ blog/2011/01/27/wheat-reaches-all-time-high/ [https://perma.cc/T9Y8-SYHV] ("Algeria's purchase of 800,000 metric tons of milling wheat this past Wednesday pushed wheat prices to an all time high of $\$ 8.61 \frac{1}{4}$ a bushel, up $2.1 \%$. Wheat prices have reached a record high, greater than during the 2007-2008 food crisis.").

8. See Kraft Foods Grp., Inc., 153 F. Supp. 3d at 1003 (stating that "[i]n developing that strategy, Plaintiff[] claim[s] that Kraft intended that the market would react to its enormous long position by increasing the price of the December 2011 futures contract and lowering the price of cash wheat available in the Toledo region."); see also Michael Brooks et al., Did Kraft Manipulate Futures? FUTURES MAG., (Sept. 29, 2015), http://www.futuresmag.com/2015/09/29/did-kraftmanipulate-futures [https://perma.cc/P8YB-Q7HR] (noting that in 2011, physical wheat was trading at a premium to wheat futures).

9. Complaint at 8, CFTC v. Kraft Foods Grp., Inc., 153 F. Supp. 3d 996 (N.D. Ill. 2015) (No. 1:15-cv-02881).

10. With futures contracts, the holder may choose to accept delivery of the commodity or "net out" the contract by executing an equal, offsetting futures contract.

11. Kraft Foods Grp., Inc., 153 F. Supp. 3d. at 1013-14.

12. Id. at 1013 .

13. A corner is the process by which a trader dominates the market for a commodity and is able to control its supply. This practice is prohibited under the Commodity Exchange Act. Id. at 1018 (discussing the definition of "corner," and establishing that the complaint filed by the CFTC does not allege a corner); see also Securities Exchange Act of 1934 § 9, 15 U.S.C. § 78j (2012) (prohibiting market manipulation). 
transactions were fictitious. ${ }^{14}$ Indeed, all Kraft's transactions, in both the physical and futures markets, were legal; yet, according to the CFTC, the company was guilty of market manipulation solely because of its intent to manipulate.

The allegations against Kraft are an example of open-market manipulation - manipulation accomplished through facially legitimate transactions. ${ }^{15}$ Allegations of open-market manipulation have become more common over the years, as the Securities Exchange Commission ("SEC"), the CFTC (collectively, the "Commissions"), and private plaintiffs bring suit alleging that traders manipulated the markets using legitimate trades. ${ }^{16}$ In seeking to impose liability for open-market manipulation, the Commissions recognize and are attempting to address the potential distortive effect of complex trading strategies and new financial products that hide behind a façade of legitimacy. ${ }^{17}$ However, the Commissions' theoretical basis for liability is woefully inadequate and does not improve the markets' functioning.

To the Commissions, the line between legitimate and manipulative conduct lies exclusively in the intent of the actor.

14. Fictitious trades include wash sales, order matching, and trading pools, practices in which ownership of the commodity or security does not change hands, but the transactions are done to give the appearance that there is trading in the commodity or security. Fictitious trades are illegal under the Commodity Exchange Act and the Securities Exchange Act of 1934. Commodity Exchange Act of 1936 \$(c), 7 U.S.C. $\$ 9$ (2012); 15 U.S.C. $§ 78 j$.

15. Maxwell K. Multer, Open-Market Manipulation Under SEC Rule 10b-5 and its Analogues: Inappropriate Distinctions, Judicial Disagreement and Case Study: FERC's AntiManipulation Rule, 39 SEC. REG. L.J. 97, 102 (2011) ("Open-market manipulations involve no objectively fraudulent or bad acts."). To be clear, the scope of this Article's analysis does not include spoofing, layering, or other algorithmic trading strategies.

16. See, e.g., ScripsAmerica, Inc. v. Ironridge Global LLC, 56 F. Supp. 3d 1121, 1134 (C.D. Cal. 2014) (involving a plaintiff that brought suit alleging that the defendant had "fraudulently manipulated the market for [plaintiff] Scrips stock . . . by 'short selling' Scrips' shares ... in an effort to drive the share price down artificially and require Scrips to issue more shares to [defendant] Ironridge pursuant to the terms of the parties' agreement"); Burt v. Maasberg, No. ELH-12-0464, 2013 U.S. Dist. LEXIS 46732, at *72 (D. Md. Mar. 31, 2013) ("[P]laintiffs allege that 'defendants,' and, in particular, Blair, engaged in market manipulation . . . conceal[ing] the group's intentions of buying Lyris stock, to drive away other investors, and to depress the price of Lyris stock.”); SEC v. Ogle, No. 99 C 609, 2000 U.S. Dist. LEXIS 239, at *18 (N.D. Ill. Jan. 10 , 2000) (explaining that the SEC alleged that the defendant acted as a statutory underwriter when selling unregistered stock during its market manipulation scheme).

17. Matthew Evans, Note, Regulating Electricity-Market Manipulation: A Proposal for a New Regulatory Regime to Proscribe All Forms of Manipulation, 113 MICH. L. REV. 585, 601-02 \& n.109 (2015) (highlighting that the CFTC has made it clear that conduct "giving rise to a manipulation charge need not itself be fraudulent or otherwise illegal," and that this allows the CFTC to target strategies and products that feign legitimacy (quoting Prohibition on Market Price Manipulation, 75 Fed. Reg. 67657, 67661 (Nov. 3, 2010) (codified as amended at 17 C.F.R. pt. 180 $(2014))))$. 
Specifically, the Commissions treat the intent of the trader to manipulate the markets as both necessary and sufficient to transform otherwise legitimate transactions into manipulation. ${ }^{18}$ Private parties alleging open-market manipulation have also adopted this approach. ${ }^{19}$ The courts, on the other hand, are less predictable in their approaches..$^{20}$ For some courts, intent alone is insufficient; these courts are unwilling to classify open-market transactions as manipulative without a showing of "something more." 21 The divergent approaches

18. Daniel R. Fischel \& David J. Ross, Should the Law Prohibit "Manipulation" in Financial Markets?, 105 HARV. L. REV. 503, 510 (1991) ("[T]here is no objective definition of manipulation. The only definition that makes any sense is subjective-it focuses entirely on the intent of the trader."); Hui Huang, Redefining Market Manipulation in Australia: The Role of an Implied Intent Element, 27 COMPANIES \& SEC. L.J. 8, 12 (2009) (“"[I]intent' is an essential element of market manipulation without which a transaction would not be manipulative at all."); see, e.g., Alexander F.H. Loke, The Investors' Protected Interest Against Market Manipulation in the United Kingdom, Australia and Singapore, 21 AUSTRALIAN J. CORP. L. 22, 24 (2007) (contending "that there is an irreducible relevance of motivations" in market manipulation cases); Lawrence Damian McCabe, Note, Puppet Masters or Marionettes: Is Program Trading Manipulative as Defined by the Securities Exchange Act of 1934?, 61 FordHAM L. REV. S207, S223 (1993) (arguing that "[t]he presence of an improper purpose . . is necessary to determine whether the activity should [have been] condemned as unlawful manipulation").

19. Compare Nanopierce Techs., Inc. v. Southridge Cap. Mgmt. LLC., No. 02 Civ.0767 LBS, 2002 WL 31819207, at $* 2$ (S.D.N.Y. Oct. 10, 2002) (acknowledging that the plaintiffs adequately pled the scienter requirement by exhibiting "both the motive and the opportunity to defraud Nanopierce" (citation omitted)), with GFL Advantage Fund, Ltd. v. Colkitt, 272 F.3d 189, 211 (3d Cir. 2001) ("Another reason why [the plaintiff's] market manipulation claim fails is because he has not met the scienter requirement by offering evidence that GFL engaged in short sales for the purpose of artificially depressing the prices of National Medical and EquiMed stock.").

20. See, e.g., GFL Advantage Fund, Ltd., 272 F.3d at 205 (explaining that market manipulation depends on the activity rather than the intent, and noting that " $[\mathrm{t}]$ he gravamen of manipulation is deception of investors into believing that prices at which they purchase and sell securities are determined by the natural interplay of supply and demand, not rigged by manipulators" (quoting Gurary v. Winehouse, 190 F.3d 37, 45 (2d Cir. 1999)); Markowski v. SEC, 274 F.3d 525, 528 (D.C. Cir. 2001) ("It may be hard to separate a 'manipulative' investor from one who is simply over-enthusiastic .... Legality would thus depend entirely on whether the investor's intent was 'an investment purpose' or 'solely to affect the price of [the] security.'" (quoting United States v. Mulheren, 938 F.2d 364, 368 (2d Cir. 1991))); CFTC v. Kraft Foods Grp., Inc., 153 F. Supp. 3d 996, 1020 (N.D. Ill. 2015) ("Intent is what separates 'lawful business conduct from unlawful manipulative activity.' . . This means that the intent to artificially affect prices can convert otherwise legal, open-market transactions into manipulative activity." (citations omitted)); CFTC v. Amaranth Advisors, L.L.C., 554 F. Supp. 2d 523, 534 (S.D.N.Y. 2008) ("Although Masri dealt with the interpretation of federal securities laws, there is no doubt that marking the close or any other trading practices, without an allegation of fraudulent conduct, can also constitute manipulation in contravention of the CEA, so long as they are pursued with a manipulative intent."); SEC v. Masri, 523 F. Supp. 2d 361, 369 (S.D.N.Y. 2007) ("[T]he Second Circuit has explicitly declined to answer the first question presented in this case-whether manipulative intent alone can support liability for otherwise legal open-market transactions.").

21. See Mulheren, 938 F.2d at 371 (emphasizing that absent bad acts, the plaintiff needs to prove manipulative intent and also "other indicia of manipulation"); In re Coll. Bound Consol. 
of the Commissions and the courts add an uncomfortable level of unpredictability to the markets, thus muddying an already chaotic corner of financial regulation.

Open-market manipulation and the Commissions' current theory of liability raise noteworthy questions that are largely unaddressed in academic literature on market manipulation. Anti-manipulation laws are geared toward making the markets safer and more efficient for investors. Yet, in targeting conduct that is illegitimate solely because of the intent of the trader, the Commissions' approach to open-market manipulation has arguably deviated from their statutory purposes. The intent-centric approach of the government to open-market manipulation is a significant departure from the traditional conceptualization of market manipulation as conduct that is both harmful to the markets and accompanied by bad intent. Indeed, as this Article demonstrates, the Commissions' intent-centric approach to open-market manipulation lacks a coherent basis for liability and weakens the efficacy of anti-manipulation enforcement actions.

This Article addresses the issue of open-market manipulation by seeking to answer two foundational questions. First, can facially legitimate transactions be manipulative (that is, improperly distort the markets)? Second, if yes, on what basis should open-market transactions be considered manipulative from a legal standpoint? ${ }^{22}$ As to the first question, this Article argues that open-market transactions can distort the markets. However, unlike the Commissions, this Article rejects intent as the sole basis for deeming legitimate yet manipulative

Lit., Nos. 93 Civ. 2348 (MBM), 94 Civ. 3033 (MBM), 1995 WL 450486, at *6 (S.D.N.Y. July 31, 1995) (explaining that open-market manipulation claims have to plead the following elements: "1) 'profit or personal gain to the alleged manipulator'; 2) deceptive intent; 3) market domination; and 4) economic reasonableness of the alleged manipulation" (quoting Mulheren, 938 F.2d at 37072)); Hillary A. Sale \& Donald C. Langevoort, "We Believe": Omnicare, Legal Risk Disclosure and Corporate Governance, 66 DUKE L.J. 763, 785-86 (2016) (discussing the courts' definition of corporate scienter as a struggle to define "that scope of knowledge in a way that syncs to investors' reasonable expectations").

22. This Article faces its own internal conundrum that "manipulation" (and its derivatives) may refer to both (1) the act of distorting the market and (2) the legal claim of market manipulation. As best as possible, this Article delineates when it uses manipulation to refer to the act of distorting the market and when manipulation refers to an illegal act for which there is a legally cognizable claim, recognizing that not all distortive trades are per se legal violations. Thus, this Article uses "manipulative acts" (or something similar) to refer to trades that distort the market as a descriptive (not legal) matter; "manipulation," "market manipulation," and "illegal manipulation" (and their derivatives) are used to refer to manipulative acts that are also legal violations of anti-manipulation laws and regulations. For a discussion of the legal definitions of manipulation, see infra Part I.B. 
transactions illegal. Intent is a necessary component of identifying open-market manipulation, but it is not sufficient on its own. The Commissions' intent-centric basis of liability ignores the most important aspect of open-market manipulation-harm to the market. To the extent that open-market transactions harm the markets, they should be treated as illegal manipulation. This Article offers an alternative legal approach to open-market manipulation that looks both at the intent of the trader and the harm of her conduct on the markets. This Article's proposed approach to open-market manipulation moves the inquiry beyond the intent of the trader to answer the fundamental question of why some legitimate transactions may nonetheless be wrongful. By adopting a market-harm approach to open-market manipulation, lawmakers and the courts can begin to develop more coherent principles for identifying and addressing this form of market manipulation.

This Article is the first that analyzes the fundamental question of open-market manipulation in the securities and commodities markets from a legal standpoint. By focusing on the harm the transaction imposes on the market, this Article demonstrates that open-market transactions can be used to illegally manipulate the markets, and that the legitimacy of the underlying transactions does not render the conduct any less harmful to the markets. Instead of looking for "something more" or for wrongful conduct in order to hold a trader liable for open-market manipulation, lawmakers and courts should focus on the impact of the transactions on the markets. Analyzing open-market manipulation through its effect on the market would empower lawmakers to ignore the red herring of the transactions' legitimacy and would allow them to instead concentrate on the harm of the transactions. A market-harm approach would thereby allow for an appropriate separation of illegally manipulative conduct from permissible transactions. To meaningfully ground liability for openmarket manipulation on harm to the market, it is necessary to define harm. This Article defines harm with reference to the goals of antimanipulation laws and the types of manipulative conduct that these laws target. Specifically, open-market trades can harm the markets by (1) undermining market efficiency by creating an artificial price and (2) impairing market integrity by creating unfair and dishonest market conditions.

This Article proceeds in the following order. Part I details the goals and content of anti-manipulation laws. It also defines market manipulation from a structural standpoint, discussing the necessary 
components of manipulation. Part II introduces the concept of openmarket manipulation and, through the use of case studies, establishes how facially legitimate transactions may nevertheless distort the market. Notably, the case studies also demonstrate the shortcomings of the Commissions' intent-centric theoretical basis for open-market manipulation. Part II concludes that intent fails to adequately capture and deter illegal manipulation accomplished through facially legitimate transactions. Part III asserts this Article's thesis and primary contribution to manipulation law and scholarship-liability for openmarket manipulation must be based on whether the transactions harm the markets' efficiency, integrity, or both. Part III analyzes how openmarket manipulation distorts asset prices and therefore impairs the integrity of the market, similar to more easily identifiable forms of illegal market manipulation. Part III also argues in favor of a new basis of liability for open-market manipulation-whether the transaction was unfair to counterparties because it resulted in unjust wealth transfers, which ultimately undermine market integrity. In addition, Part III considers what role market discipline may play in limiting the effect of open-market manipulation on the markets. Part III outlines a proposal to assist lawmakers in improving detection and enforcement of open-market manipulation. Part IV discusses the benefits and potential drawbacks of this Article's proposal.

\section{A PRIMER ON MARKET MANIPULATION}

Preventing market manipulation was one of the initial motivators behind the adoption of the securities and commodities laws. Although the purpose of financial-market regulations and laws has since been extended, identifying, proscribing, and punishing market manipulation remains one of the primary goals of the Commissions in their oversight of the financial markets. This Part discusses the overarching goals of manipulation laws and regulation to provide a foundational understanding of why these laws exist. Part I goes on to discuss how market manipulation is defined both theoretically and statutorily.

\section{A. Goals of Manipulation Laws}

Market manipulation imposes significant social and financial costs on the financial markets. ${ }^{23}$ Because of this welfare-reducing impact on

23. Marcel Kahan, Securities Laws and the Social Costs of "Inaccurate" Stock Prices, 41 DUKE L.J. 977, 1006-07 (1992) (explaining that inaccurate stock prices induce corporations to 
the markets, both the Securities Exchange Act of 1934 (the "Exchange Act") and the Commodity Exchange Act (the "CEA") (collectively, "the Acts") identify the prevention of manipulation as one of their primary goals. ${ }^{24}$ Market manipulation undermines the fundamental operation of the financial markets - to facilitate the efficient allocation of capital within the markets. ${ }^{25}$ Indeed, manipulation has far-reaching consequences beyond the capital markets; it affects investments, consumer savings, and numerous aspects of the real economy. ${ }^{26}$ Manipulation harms the market in two related ways. First, it undermines the market's efficiency by distorting its pricing mechanisms. ${ }^{27}$ Second, it impairs the market's integrity because the conduct can lead other market participants to believe the market is

take actions that do not maximize their utility, while accurate stock prices facilitate efficient allocation of resources and encourage corporations to act in a manner that is socially desirable); see also William W. Bratton \& Michael L. Wachter, Shareholders and Social Welfare, 36 SEATTLE U. L. REV. 489, 498 (2013) (noting that under welfare economics, a general equilibrium theory posits "that a competitive equilibrium is good for the economy because it maximizes wealth" and that, therefore, activity that is anticompetitive or manipulative will result in suboptimal results that are likely to be economically harmful); Craig Pirrong, Energy Market Manipulation: Definition, Diagnosis, and Deterrence, 31 ENERGY L.J. 1, 4 (2010) (explaining that market manipulation is socially costly since "[i]t distorts prices, and typically leads to distortions in commodity flows").

24. 7 U.S.C. $\$ 6 c$ (2012) (prohibiting manipulative strategies, such as wash sales and fictitious sales, that aim to cause a change in the "bona fide price" of a commodity); 15 U.S.C. $§ 78 \mathrm{j}$ (prohibiting the use of manipulative devices in connection with the sale or purchase of any security). For example, in enacting the Exchange Act, Congress expressed its belief that manipulation of the securities markets is the cause of "widespread unemployment and dislocation of trade, transportation, and industry." 15 U.S.C. $§ 78 \mathrm{~b}$. With regards to the CEA, Congress concluded that regulation of futures trading is necessary because futures transactions are "susceptible to manipulation and control" and may generate sudden changes in the market. Id.

25. Benjamin P. Edwards, Conflicts \& Capital Allocation, 78 OHIO ST. L.J. 181, 185 (2017) ("The capital markets exist for two purposes: (i) to allocate capital to the most profitable opportunities (on the macroeconomic level); and (ii) to help market participants invest or borrow money (on the microeconomic level)." (citation omitted)); Zohar Goshen \& Gideon Parchomovsky, The Essential Role of Securities Regulation, 55 DUKE L.J. 711, 713 (2006) ("[T]he ultimate goal of securities regulation is to attain efficient financial markets and thereby improve the allocation of resources in the economy."); Charles K. Whitehead, Reframing Financial Regulation, 90 B.U. L. REV. 1, 35 (2010) ("The basic goals of the markets have remained the same-namely, the efficient allocation, transfer, and deployment of capital resources and riskbearing.").

26. Merritt B. Fox, Randall Morck, Bernard Yeung \& Artyom Durnev, Law, Share Price Accuracy, and Economic Performance: The New Evidence, 102 MICH. L. REV. 331, 368 (2003) ("[T] he empirical evidence suggests that the efficiency of the real economy (the actual production of goods and services) is enhanced when share prices become more accurate.").

27. Goshen \& Parchomovsky, supra note 25, at 714 ("More accurate share prices and more liquid trading enhance the efficiency of financial markets."). 
unfair. ${ }^{28}$ Consequently, if left unchecked, manipulation can eventually lead to the demise of the market. ${ }^{29}$

1. Market Efficiency. Efficient markets incorporate information, accurately and quickly, into the prices of securities and commodities (collectively, "assets"). ${ }^{30}$ Two hallmark features of market efficiency are price accuracy and high liquidity. ${ }^{31}$ Liquidity refers to the ready availability of other traders with whom to transact in the markets and the ability of traders to execute transactions without significant market movement. ${ }^{32}$ Greater liquidity increases the accuracy of the market price for an asset; more accurate asset prices lead to greater liquidity. ${ }^{33}$

28. Robert J. Haft, The Effect of Insider Trading Rules on the Internal Efficiency of the Large Corporation, 80 MicH. L. REV. 1051, 1051 (1982) ("If the public believes that the game is unfair and chooses not to play, the markets will suffer and the efficient allocation of capital will be impeded."). But see Jill E. Fisch, Family Ties: Salman and the Scope of Insider Trading, 69 STAN. L. REV. ONLINE 46, 46 (2016) (noting that because "federal securities laws do not prohibit all trading on material nonpublic information," it is clear that not all participants begin the trading process with equal information, which may lead to unfairness).

29. Carole Comerton-Forde \& James Rydge, Market Integrity and Surveillance Effort, $29 \mathrm{~J}$. FIN. SERV. RES. 149, 149 (2006) ("Market integrity refers to the ability of investors to transact in a fair and informed market where prices reflect information.").

30. Goshen \& Parchomovsky, supra note 25, at 721 ("In efficient markets, information about the value of firms is incorporated quickly and accurately into stock prices."); Lynn A. Stout, The Mechanisms of Market Inefficiency: An Introduction to the New Finance, 28 J. CORP. L. 635, 639 (2003) (“[A] market is 'efficient' when prices always fully reflect available information." (citation omitted)).

31. Goshen \& Parchomovsky, supra note 25, at 714 ("The two main determinants of market efficiency are share price accuracy and financial liquidity."); see also Hillary A. Sale \& Robert B. Thompson, Market Intermediation, Publicness, and Securities Class Actions, 93 WASH U. L. REV. 487, 494 (2015) ("Market efficiency and intermediation play a role in both facilitating securities offerings and enabling the class action that helps support the deterrence and enforcement necessary to create strong and healthy markets.").

32. Douglas J. Elliott, Market Liquidity: A Primer, Brookings Inst. 3 (June 2015), https://www.brookings.edu/wp-content/uploads/2016/07/Market-Liquidity.pdf

[https://perma.cc/QVA9-J6QT] (explaining that liquidity emerges from ease of transactions based on time restraints, minimal transaction costs, and presence of potential buyers willing to pay theoretical market value); Myles Udland, The Market is Getting Nervous About Something Experts are Struggling to Define, Bus. INSIDER (Apr. 26, 2015 7:31 AM), http://www.businessinsider.com/liquidity-in-the-bond-market-2015-4 [https://perma.cc/YF4HQC2K] (explaining that a liquid market is one in which trades can be executed with some immediacy at low transaction costs).

33. Nicholas L. Georgakopoulos, The Logic of Securities LaW 144 (2017) ("Greater trading activity translates into greater liquidity directly.... The economic force leading from liquidity to accurate prices rests on the reality that liquidity attracts informed trading."); Patricia A. McCoy, Andrey D. Pavlov \& Susan M. Wachter, Systemic Risk Through Securitization: The Result of Deregulation and Regulatory Failure, 41 CONN. L. REV. 1327, 1373 (2009) ("Liquidity is one very important component of any market; it insures the accurate pricing of securities."). 
Consequently, both accurate pricing and liquidity are essential to efficient capital allocation in the financial markets. ${ }^{34}$

Manipulation causes market inefficiency and capital misallocation by interfering with the pricing accuracy of the markets in two ways. First, asset prices are made less accurate as misinformation is injected into the markets. ${ }^{35}$ As inaccurate information is incorporated into the price of the asset, the market price moves further away from the value of the asset. ${ }^{36}$ False information, therefore, inhibits the ability of the markets to efficiently price assets and impairs the markets' functioning. Second, manipulation may create a false appearance of liquidity in the markets, resulting in an artificial asset price. ${ }^{37} \mathrm{~A}$ manipulator who creates the illusion that there is more trading in an asset than there is in actuality, is distorting the levels of liquidity to exert pressure on the asset's price.

Distorted pricing, accomplished through either or both mechanisms, is detrimental to the markets' fundamental purpose - the efficient allocation of capital. ${ }^{38}$ Anti-manipulation laws aim to reduce or eliminate transactions that undermine the ability of the markets to facilitate accurate, efficient price discovery. ${ }^{39}$ When manipulation impacts asset prices, the result is an inefficient allocation of capital, which, in turn, harms the aggregate social welfare as wealth is transferred from innocent investors to manipulators. ${ }^{40}$ To the extent

34. Charles K. Whitehead, The Volcker Rule and Evolving Financial Markets, 1 HARV. BUS. L. REV. 39, 55-56 (2011) (explaining that banks and market makers "facilitate capital-raising by providing investors with liquidity ... without interrupting the end-user's longer-term employment of capital.").

35. Kahan, supra note 23, at 987 ("[T] he amount and nature of the economic losses caused by inaccurate stock prices depend critically on the kind of mispricing.").

36. See Bratton \& Wachter, supra note 23 , at 504 ("[T] he market price is set under conditions of information asymmetry, and thus the market price is not fully informed."); Steve Thel, Regulation of Manipulation Under Section 10(b): Security Prices and the Text of the Securities Exchange Act of 1934, 1988 COLUM. BUS. L. REV. 359, 398 ("Prices may change in response to false or misleading communications since security prices reflect what investors believe, even if those beliefs are wrong.").

37. James Wm. Moore \& Frank M. Wiseman, Market Manipulation and the Exchange Act, 2 U. CHI. L. REV. 46, 50 (1934) (stating that manipulation leads to artificial and controlled prices).

38. See Goshen \& Parchomovsky, supra note 25, at 730 ("The larger the deviation between price and value and the longer it takes for prices to revert to value, the less efficient the market is.").

39. Id. at 713 (explaining that "the ultimate goal of securities regulation is to attain efficient financial markets and thereby improve the allocation of resources in the economy").

40. See William W. Bratton \& Michael L. Wachter, The Political Economy of Fraud on the Market, 160 U. PA. L. REV. 69, 104 n.131 (2011) ("The threshold question for FOTM [fraud-onthe-market] concerns the calculation of ... net harm. An underdiversified informed trader who 
that both the supply and demand of an asset and the information related to the asset are distorted, market actors may direct their resources toward assets or investments that are not accurately priced, thereby reducing the utility of the markets to investors as a whole. ${ }^{41} \mathrm{In}$ determining whether conduct is manipulative, therefore, lawmakers must consider whether it results in inefficient pricing, thereby impairing capital allocation.

2. Market Integrity. Market integrity is a broad term that refers to notions of market fairness, investor protection, and the absence of misinformation and market abuse. ${ }^{42}$ The actual and perceived integrity of the financial markets are crucial to their ability to attract capital; investors invest only to the extent that they believe the markets are fair. ${ }^{43}$ Should investors see the markets as unfair, honest investors would refrain from participating, and those that participate in the

suffers a loss might take steps to avoid future loss by incurring information costs. This is a social cost, as it is cheaper for companies to tell the truth."); Goshen \& Parchomovsky, supra note 25, at 726 ("[T] rading against a party with superior information or based on fraudulent information will result in a loss."); Tom C.W. Lin, The New Market Manipulation, 66 EMORY L.J. 1253, 128081 (2017) ("Manipulated markets not only distort the prices and transactions in one marketplace, but they also have important implications for capital allocation, investments, and savings in other markets and the greater economy.").

41. Janet Austin, What Exactly is Market Integrity? An Analysis of One of the Core Objectives of Securities Regulation, 8 WM. \& MARY BUS. L. REV. 215, 232 (2017) ("If prices reflect an asset's fundamental value, this will result in the most efficient allocation of capital, as investors will pay no more for securities than their inherent value.").

42. Donald Margotta, Market Integrity, Market Efficiency, Market Accuracy, 17 Bus. REV., CAMBRIDGE 14, 14 (2011).

43. Haft, supra note 28 , at 1051 ("If the public believes that the game is unfair and chooses not to play, the markets will suffer and the efficient allocation of capital will be impeded."). This is a classic "lemons market" as first described by George Akerlof. According to Akerlof, in a market in which buyers do not know which cars are worth their asking price and which are not (that is, the lemons), the buyer will simply treat all cars like lemons. The result will be that worthy car sellers will leave the markets, unable to get an accurate price for their products, and lemon sellers will remain in the market. See George A. Akerlof, The Market for "Lemons": Quality Uncertainty and the Market Mechanism, 48 Q. J. ECON. 488, 489-90 (1970). The characteristics of lemons markets have also been laid out in more recent scholarship:

[A] lemons market exists when four conditions are fulfilled: (1) the products on the market vary significantly in the extent to which they have certain properties ... and buyers regard products with the properties in question as having less expected value than those without them; (2) there is an asymmetry of information where buyers cannot discriminate between products with the properties and those without, but sellers can at least partially distinguish them; and furthermore, (3) there is no reliable signal of quality ... however, (4) buyers know there is a mix of products on the market.

Richard Warner \& Robert H. Sloan, Vulnerable Software: Product-Risk Norms and the Problem of Unauthorized Access, 2012 U. ILL. J.L. TECH. \& POL'Y 45, 83-84 (2012). 
markets would discount all information and transactions. ${ }^{44}$ The connection to market efficiency is clear. If investors refuse to participate in the markets, this will make the markets less liquid because there are fewer traders, which in turn makes prices less accurate and the markets less efficient. Consequently, although market integrity deals with the less-defined concept of fairness, it is crucial to efficient capital allocation.

Manipulation adversely impacts market integrity because it allows bad actors to exploit other traders in the markets. Market manipulators are able to profit at the expense of others, not owing to diligence, research, or luck, but rather because of an unfair advantage. ${ }^{45}$ To the extent that investors perceive the markets as unfair, they limit the capital they invest in the markets. Indeed, when investors question the integrity of the markets, there is a dearth of capital available within the markets as a whole, as was evidenced after the corporate frauds of Enron $^{46}$ and WorldCom were exposed ${ }^{47}$ Maintaining market integrity and the perception of fairness in the markets is critical to the proper functioning of the financial markets. ${ }^{48}$ Thus, effective regulation addressing market manipulation must consider both the harm the conduct has on the integrity of the market and notions of fairness.

44. See Dionigi Gerace et al., Stock Market Manipulation on the Hong Kong Stock Exchange, 8 AUSTRALASIAN ACCT., BUS. \& FIN. J. 105, 136 (2014) ("Manipulation is also associated with increased volatility and reduced volume as investors exit the market rationally in fear of trading with a manipulator."); Haft, supra note 28, at 1051 ("[T]aking advantage of inside information that is unavailable to other parties is inherently unequitable. ... [I]nsiders unfairly obtain benefits from and damage the public investor on the other side of the trade.").

45. See Tom C.W. Lin, supra note 40, at 1281 (stating that "the goal of ... market manipulation is to distort the natural price of certain financial instruments or transactions to the benefit of the manipulative party").

46. Iman Anabtawi \& Steven L. Schwarcz, Regulating Systemic Risk: Towards an Analytical Framework, 86 NOTRE DAME L. REV. 1349, 1359 (2011) ("Enron failed to appreciate the risk that a fall in the value of its merchant assets could be coupled with a significant fall in the price of Enron stock used as collateral, and that the firm would collapse as a result.").

47. Emilios Avgouleas, The Mechanics and Regulation of Market Abuse: A LEGAL AND ECONOMIC ANALYSIS 212 (2005) ("Such misallocation of resources has a detrimental effect for the economy as a whole, and this can be witnessed by the dearth of capital available for investment that followed the recent stock bubble and the eruption of the Enron, WorldCom, Adelphia, and other corporate frauds.").

48. See Haft, supra note 28 , at 1051 ("If the public believes that the game is unfair and chooses not to play, the markets will suffer and the efficient allocation of capital will be impeded."); Margotta, supra note 42, at 14 ("[G]reater market integrity will lead to security prices that more closely reflect the value of securities."). 


\section{B. Defining Market Manipulation}

One of the primary difficulties in dealing with market manipulation is the absence of an agreed-upon definition. ${ }^{49}$ Securities and commodities laws and regulations do not define illegal manipulation. Instead, the Acts prohibit specific conduct-such as fictitious trades-and generally harmful conduct-such as fraud, deception, and price manipulation. ${ }^{50}$ To some, the lack of a definition is a grave oversight of lawmakers and is the reason for the confusion that exists in the law of market manipulation. ${ }^{51}$ But given that " $[\mathrm{t}] \mathrm{he}$ methods and techniques of manipulation are limited only by the ingenuity of man," 52 any definition of illegal manipulation must be capacious enough to evolve with the markets, while still establishing meaningful boundaries as to what conduct is considered manipulative..$^{33}$

In defining illegal manipulation, courts have largely relied on vague notions of price artificiality and on willful market misconduct

49. See John C. Coffee, Jr., Introduction: Mapping the Future of Insider Trading Law: Of Boundaries, Gaps, and Strategies, 2013 CoLUM. BUS. L. REV. 281, 289 n.16 (2013) (“'[M]anipulation' and 'manipulative' are terms of art that the Supreme Court has long narrowly construed to exclusively cover practices 'intended to mislead investors by artificially affecting market activity.' Hence, neither 'contrivance' nor 'manipulative' in Section 10(b) add much, if anything, to its coverage.” (quoting Santa Fe Indus., Inc. v. Green, 430 U.S. 462, 476 (1977))); Amanda N. Miller, Securities and Commodities Manipulation: Is There a Principled Reason to Distinguish the Two?, 17 PIABA BAR J. 1, 1 (2010) ("Congress did not define the term 'manipulation' under [the CEA nor the Exchange Act], thus leaving it to the courts to define securities and commodities manipulation.”); Tālis J. Putniņs, Market Manipulation: A Survey, 26 J. ECON. SURVS. 952, 953 (2012) ("There is no generally accepted definition of market manipulation .... Legal definitions are often intentionally not explicit, and much of the finance and economics literature uses the term market manipulation in an imprecise manner.").

50. See, e.g., 7 U.S.C. $\S 6 c$ (2012) (prohibiting the use of a fictitious sale in the purchase or sale of any commodity to distort the "bona fide price" of such commodity); 15 U.S.C. $§ 78 j$ (prohibiting the use of any manipulative or deceptive device in connection with the sale or purchase of any security); Robert B. Thompson \& Hillary A. Sale, Securities Fraud as Corporate Governance: Reflections upon Federalism, 56 VAND. L. REV. 859, 872 (2003) ("The two most prominent mechanisms [of an increased federal role in corporate governance] are the periodic disclosure requirements under section 13 and the antifraud provisions and concomitant liability under section 10(b) and Rule 10b-5.").

51. See, e.g., Edward T. McDermott, Defining Manipulation in Commodity Futures Trading: The Futures "Squeeze," 74 Nw. U. L. REV. 202, 205 (1979) (calling manipulation law "an embarrassment-confusing, contradictory, complex, and unsophisticated").

52. JERRY W. MARKHAM, LAW ENFORCEMENT AND THE History OF FINANCIAL MARKET MANIPULATION 147 (2014).

53. As one court opined, "Congress' decision to prohibit manipulation without defining it apparently arose from the concern that clever manipulators would be able to evade any legislated list of proscribed actions or elements of such a claim." In re Soybean Futures Litig., 892 F. Supp. 1025, 1044 (N.D. Ill. 1995). 
that impacts price. For example, the Supreme Court has stated, "'Manipulation' is 'virtually a term of art when used in connection with securities markets.' The term refers generally to practices ... that are intended to mislead investors by artificially affecting market activity." ${ }^{54}$ The Court has also stated that manipulation "connotes intentional or willful conduct designed to deceive or defraud investors by controlling or artificially affecting the price of securities." has given meaning to the scienter requirement by way of the "statutory authorization for the main antifraud prohibitions in the securities laws... [mandating] intentionality, something more than negligence. ${ }^{56}$ Similarly, in interpreting manipulation under the CEA, one court stated: "[T] he test of manipulation must largely be a practical one .... The aim must be therefore to discover whether conduct has been intentionally engaged in which has resulted in a price which does not reflect basic forces of supply and demand." 57

Some scholars have attempted to be more precise in their definitions of manipulation. For example, Matthijs Nelemans defines manipulation in relation to the effect the conduct has on the price of the asset, but he does not refer to this as an "artificial price," as the courts do, because of the supposed difficulties in determining when a price is artificial..$^{58}$ To Nelemans, manipulation is conduct that creates an extraneous or improper effect on price. ${ }^{59}$ Other scholars define manipulation as an abuse of market power that improperly impacts market price.$^{60}$ Most notably, Professors Thomas Lee Hazen and Philip

54. Santa Fe Indus., Inc., 430 U.S. at 476-77 (internal quotations and citations omitted).

55. Ernst \& Ernst v. Hochfelder, 425 U.S. 185, 199 (1976) (citation omitted).

56. Donald C. Langevoort, What Were They Thinking? Insider Trading and the Scienter Requirement, in RESEARCH HANDBOOK ON INSIDER TRADING 53 (Stephen Bainbridge ed., 2013) (citing Hochfelder, 425 U.S. 185).

57. Cargill, Inc. v. Hardin, 452 F.2d 1154, 1162 (8th Cir. 1971). John George Smith, too, described manipulation as involving price artificiality and willful misconduct:

"Manipulation" is a vague term used in a wide and inclusive manner, possessing varying shades of meaning, and almost always conveying the idea of blame-worthiness deserving of censure. There is usually also an implication of artificiality and of skilful and ingenious management .... [I]ts most common use ... [is] in such a way as to give outsiders the impression that such buying or selling is the result of natural forces.

John GeOrge SMith, ORGanised Produce MARKets 109-10 (1922).

58. See generally Matthijs Nelemans, Redefining Trade-Based Market Manipulation, $42 \mathrm{VAL}$. U. L. REV. 1169 (2008) (describing how manipulation creates extraneous or improper "price pressure").

59. Id. at 1175 .

60. Donald C. Langevoort, Taming the Animal Spirits of the Stock Markets: A Behavioral Approach to Securities Regulation, 97 Nw. U. L. REV. 135, 161 (2002) ("[M]anipulation is concerned less with the immediate victim than the integrity of the market."). 
McBride Johnson define price manipulation as "the elimination of effective price competition in a market for cash commodities or futures contracts (or both) through the domination of either supply or demand, and the exercise of that domination intentionally to produce artificially high or low prices." ${ }^{\prime 1}$

Despite their substantive differences, from a structural standpoint, most definitions of manipulation are quite similar. All the definitions aim to capture the wrongfulness of manipulation in terms of deliberate conduct, nonnegligent behavior, deception, artificial market conditions, misleading information, fraudulent actions, or some combination thereof. Thus, attempts to define manipulation frame the misconduct as both intentional and harmful. Undoubtedly, these definitions differ in what constitutes harm and how the harm ought to be measured or identified. But structurally, market manipulation is based on the trader's scienter and the harm she inflicts on the marketboth of which are necessary.

This Article adopts this structural approach to manipulationconduct must be both intentional and harmful to the market to satisfy any definition of manipulation. Notably, this Article views harm in relation to the goals of anti-manipulation laws. Meaning, conduct is harmful if it either (1) impedes the markets' efficiency, such as through interfering with price accuracy or negatively impacting liquidity, or (2) impairs the markets' integrity, such as through unfair practices that exploit the markets or other traders. As explained in the discussion of anti-manipulation laws below, all traditional understandings of market manipulation entail both intent and harm. Open-market manipulation, therefore, should be no different.

\section{Anti-Manipulation Laws}

Anti-manipulation laws in the United States are divided between the Exchange Act and related regulations, ${ }^{62}$ and the CEA and related regulations. ${ }^{63}$ Owing to the historical separation of the securities and

61. 3 Philip McBride Johnson \& Thomas LeE HaZen, Derivatives Regulation 1240 (3d ed. 2004).

62. Securities and Exchange Act of 1934, 15 U.S.C. 78i (2012) (prohibiting price manipulation); 15 U.S.C. $§ 78 j$ (2012) (prohibiting fraud and manipulation in the securities markets); SEC Rules and Regulations Under the Securities Exchange Act of 1934, 17 C.F.R. $\S 240.10$ b-5 (2018) (codifying the prohibitions of 15 U.S.C. $\S 78 \mathrm{j}$ against fraud-based manipulation).

63. Commodity Exchange Act of 1936, 7 U.S.C. $§ 6 c$ (2012) (prohibiting manipulative and disruptive trading strategies); 7 U.S.C. $\$ 9$ (2012) (prohibiting manipulation and false 
commodities markets, their anti-manipulation provisions have evolved along different paths. But with the convergence of these markets, there have been efforts in recent years to have the anti-manipulation regimes of the two markets mirror each other as closely as possible. ${ }^{64}$ The Acts broadly proscribe three categories of manipulative behavior: (1) fraud and misstatements, (2) fictitious trades, and (3) price manipulation.

1. Fraud and Misstatements. Fraud and misleading statements are the least controversial form of market manipulation, likely owing to their common law roots. The best-known anti-manipulation provision is section 10(b) of the Exchange Act, which grants the SEC broad authority to prohibit "manipulative and deceptive devices and contrivances" in relation to the purchase or sale of a security. ${ }^{65}$ Based on section 10(b), the SEC promulgated Rule 10b-5, which prohibits fraud, deception, and material misstatements. ${ }^{66}$ Thus, manipulation came to be viewed as a species of fraud, and the law developed accordingly ${ }^{67}$ The case law applying and interpreting section $10(\mathrm{~b})$ and

information); CFTC Prohibition Against Manipulation, 17 C.F.R. § 180.1 (2018) [hereinafter Rule 180.1] (codifying prohibitions of 7 U.S.C. $\$ 9(1)$ against fraud-based manipulation); CFTC Prohibition Against Manipulation, 17 C.F.R. $§ 180.2$ (2018) (codifying prohibitions of 7 U.S.C. $\S$ 9(3) against price manipulation).

64. See, e.g., U.S. CFTC \& U.S. SEC, A JOINT REPORT OF THE SEC AND THE CFTC ON HARMONIZATION OF REGULATION 51-54 (Oct. 16, 2009), https://www.cftc.gov/sites/default/ files/stellent/groups/public/@otherif/documents/ifdocs/opacftc-secfinaljointreport101.pdf [https://perma.cc/FUS4-BCH7] (identifying areas in which the Commissions' anti-manipulation laws diverge); see also DEP'T OF THE TREASURY, FINANCIAL REGUlATORY REFORM: A NEW FOUNDATION: REBUILDING FINANCIAL SUPERVISION AND REGULATION 50-51 (2009), https://www.treasury.gov/initiatives/Documents/FinalReport_web.pdf [https://perma.cc/NF6ADDYF] (requesting that the Commissions identify areas of differing regulations and recommend statutory amendments that would eliminate these differences).

65. 15 U.S.C. $\$ 78$ j.

66. Rule 10b-5 reads:

It shall be unlawful for any person, directly or indirectly, by the use of any means or instrumentality of interstate commerce, or of the mails or of any facility of any national securities exchange,

(a) To employ any device, scheme, or artifice to defraud,

(b) To make any untrue statement of a material fact or to omit to state a material fact necessary in order to make the statements made, in the light of the circumstances under which they were made, not misleading, or

(c) To engage in any act, practice, or course of business which operates or would operate as a fraud or deceit upon any person,

in connection with the purchase or sale of any security.

17 C.F.R. $\$ 240.10 b-5$ (2018).

67. See John F. Barry III, The Economics of Outside Information and Rule 10b-5, 129 U. PA. L. REV. 1307, 1366-69 (1981) (explaining that the historical impetus for section 10(b) and Rule $10 \mathrm{~b}-5$ was the need for a federal prohibition against common law fraud in the securities markets). 
Rule 10b-5 imported the principles of common law fraud into the law of manipulation. ${ }^{68}$ To allege a claim under section $10(\mathrm{~b})$ and Rule 10b5 , the plaintiff must demonstrate that (1) the defendant made a material misstatement or omission or used a fraudulent device, (2) she did so with scienter (that is, intent), (3) her conduct was related to the purchase or sale of a security, (4) the plaintiff relied on the misstatement, and (5) the plaintiff was harmed. ${ }^{69}$

Unlike the SEC's section 10(b) authority, Congress only granted the CFTC fraud-based anti-manipulation authority in $2010 .^{70}$ Section 6(c)(1) of the CEA and Rule 180.1 are almost mirror images of section 10(b) and Rule 10b-5, and they prohibit the same conduct. ${ }^{71} \mathrm{By}$

68. See id. at $1367-68$.

69. ATSI Commc'ns, Inc. v. Shaar Fund, Ltd., 493 F.3d 87, 105 (2d Cir. 2007) (citation omitted); see also United States v. Mulheren, 938 F.2d 364, 368-69 (1991) (explaining that to establish a claim under $10 \mathrm{~b}-5$, the Government must prove that the defendant's purpose was to affect the price of the security through his transactions, and that the defendant was not acting merely with "the intent to invest"); James J. Park, Rule 10b-5 and the Rise of the Unjust Enrichment Principle, 60 DUKE L. J. 345, 358 (2010) (noting that a Rule 10b-5 claim requires (1) "a misrepresentation or omission" that is (2) "material... [or] significant to the market or investors" and (3) is "in connection with' a securities transaction" (citations omitted)).

70. Specifically, the Dodd-Frank Wall Street Reform and Consumer Protection Act of 2010 (“Dodd-Frank Act”), Pub. L. No. 111-203, 124 Stat. 1376 (codified as amended in scattered sections of the U.S. Code), amended section 6(c) of the CEA to provide that:

It shall be unlawful for any person, directly or indirectly, to use or employ, or attempt to use or employ, in connection with any swap, or a contract of sale of any commodity in interstate commerce, or for future delivery on or subject to the rules of any registered entity, any manipulative or deceptive device or contrivance, in contravention of such rules and regulations as the Commission shall promulgate....

7 U.S.C. $\S 9(1)$.

71. Notably, the CFTC has solidified the expansive scope of the provision, stating that because section 6(c)(1) of the CEA prohibits manipulative devices in addition to deception, it is a market-manipulation provision, as opposed to simply an anti-fraud provision. See 17 C.F.R. $\S \S 180.1 \& 180.2$. Rule 180.1 states in relevant part:

(a) It shall be unlawful for any person, directly or indirectly, in connection with any swap, or contract of sale of any commodity in interstate commerce, or contract for future delivery on or subject to the rules of any registered entity, to intentionally or recklessly:

(1) Use or employ, or attempt to use or employ, any manipulative device, scheme, or artifice to defraud;

(2) Make, or attempt to make, any untrue or misleading statement of a material fact or to omit to state a material fact necessary in order to make the statements made not untrue or misleading;

(3) Engage, or attempt to engage, in any act, practice, or course of business, which operates or would operate as a fraud or deceit upon any person; or,

(4) Deliver or cause to be delivered, or attempt to deliver or cause to be delivered, for transmission through the mails or interstate commerce, by any means of communication whatsoever, a false or misleading or inaccurate report concerning crop or market information or conditions that affect or tend to affect the price of any commodity in interstate commerce, knowing, or acting in reckless disregard of the fact that such report is false, misleading or inaccurate. 
modeling Rule 180.1 on Rule $10 \mathrm{~b}-5$, the CFTC signaled its incorporation of decades of Rule 10b-5 jurisprudence and interpretation. ${ }^{72}$

2. Fictitious Trades. Another form of market manipulation over which there is little or no controversy is fictitious trading. Fictitious trades create the illusion that there is more trading in a stock than there is in fact. ${ }^{73}$ When a trader or a group of traders acting in concert trade assets - with no actual change in ownership - the result is an increase in the apparent volume of transactions in the assets. ${ }^{74}$ Examples of fictitious trades include wash sales and matched orders, schemes in which traders execute sham transactions with a known, prearranged counterparty to move an asset's price by giving the appearance of liquidity.

Both section 9(a)(1) of the Exchange Act and section 4c(a)(1) of the CEA prohibit trades that do not result in a change in beneficial ownership or that are with a prearranged counterparty. ${ }^{75}$ In either scenario, the trader does not face real financial risk, and the transactions artificially inflate the volume of trading associated with the asset, thereby affecting the price. ${ }^{76}$ Again, the transactions involved in this form of manipulation impede the operation of the markets, thereby harming the markets' allocative and pricing efficiency. Because of the complete absence of any legitimate justification for

Notwithstanding the foregoing, no violation of this subsection shall exist where the person mistakenly transmits, in good faith, false or misleading or inaccurate information to a price reporting service.

Id. $\S 180.1(\mathrm{a})$.

72. The CFTC's incorporation of Rule $10 \mathrm{~b}-5$ jurisprudence has been explicit:

Given the similarities between CEA section 6(c)(1) and Exchange Act section 10(b), the [CFTC] deems it appropriate and in the public interest to model final Rule 180.1 on SEC Rule 10b-5. To account for the differences between the securities markets and derivatives markets, the [CFTC] will be guided, but not controlled, by the substantial body of judicial precedent applying the comparable language of SEC Rule 10b-5.

Prohibition on the Employment, or Attempted Employment, of Manipulative and Deceptive Devices and Prohibition on Price Manipulation, 76 Fed. Reg. 41,398, 41,399 (July 14, 2011) (to be codified at 17 C.F.R. pt. 180).

73. 8 Bus. \& COM. LiTIG. FED. CTS. $\S 81: 14$ (4th ed.) ("[F]ictitious trades create a false impression of increased trading activity, thereby creating an impression of greater liquidity in the market for the commodity or future or suggesting that important news is soon to come.").

74. Id. (explaining that "wash trades ... are fictitious, prearranged sales in which the same parties agree to a pair of offsetting trades for the same commodity, at no economic risk or net change in beneficial ownership").

75. $\quad$ See 7 U.S.C. $\S 6 c(2012) ; 15$ U.S.C. $§ 78 i$.

76. See John L. Teall, Financial Trading And InVESTing 337 (2013). 
fictitious trades, this behavior is universally decried as improper and illegal. ${ }^{77}$

3. Price Manipulation. Price manipulation is explicitly prohibited in both Acts. Section 9(a)(2) of the Exchange Act prohibits transactions that affect the price of a security for the purpose of inducing another to buy or sell the security. ${ }^{78}$ The SEC, however, has not made much use of this provision, opting instead to rely on section 10(b) of the Exchange Act and Rule 10b-5 to prosecute manipulation. Section 6(c)(3) of the CEA also outlaws the direct or indirect manipulation of the price of a commodity or swap. ${ }^{79}$ Prior to the 2010 amendments to the CEA, price manipulation was the primary antimanipulation provision available to the Commission. ${ }^{80}$ As such, unlike the SEC, the CFTC has had to rely heavily on this provision to address market manipulation.

The elements of price manipulation include both intent and harm. To successfully allege price manipulation, a plaintiff must show that: (1) the defendant possessed an ability to influence market prices; (2) an artificial price existed; ${ }^{81}(3)$ the defendant caused the artificial price;

77. See Gregory Scopino, Do Automatic Trading Systems Dream of Manipulating the Price of Futures Contracts? Policing Markets for Improper Trading Practices by Algorithmic Robots, 67 FLA. L. REV. 221, 263-64 (2015) (discussing the unlawfulness of transactions that are noncompetitive or that are believed to facilitate noncompetitive trading under section $4 \mathrm{c}(\mathrm{a})$ and discussing Congress's desire to outlaw trading schemes that give the appearance of trading in an open market while negating the risk of price competition in that market).

78. Section 9(a)(2) states:

It shall be unlawful for any person, directly or indirectly, by the use of the mails or any means or instrumentality of interstate commerce, or of any facility of any national securities exchange, or any member of a national securities exchange ... [t]o effect, alone or with 1 or more other persons, a series of transactions in any security registered on a national securities exchange, any security not so registered, or in connection with any security-based swap or security-based swap agreement with respect to such security creating actual or apparent active trading in such security, or raising or depressing the price of such security, for the purpose of inducing the purchase or sale of such security by others.

15 U.S.C. $\S 78 \mathrm{i}(\mathrm{a})(2)$.

79. 7 U.S.C. $\$ 9$ (prohibiting "directly or indirectly, [the] use or employ ... in connection with any swap, or a contract of sale of any commodity... [of] any manipulative or deceptive device").

80. Craig Pirrong, The Economics of Commodity Market Manipulation: A Survey, 5 J. COMMODITY MKTS. 1, 13 (2017) ("In 2010, believing that the CEA's existing anti-manipulation provisions were inadequate, Congress added language to the law as part of Dodd-Frank that effectively incorporated the anti-manipulation provisions of the Securities Act ....").

81. An artificial price is a price that does not reflect basic forces of supply and demand. In re Ind. Farm Bureau Coop. Ass'n, Inc., No. 75-14, 1982 WL 30249, at *7 (C.F.T.C. Dec. 17, 1982). 
and (4) the defendant specifically intended ${ }^{82}$ to cause the artificial price. ${ }^{83}$ The requirement that the plaintiff prove both specific intent and price artificiality is the reason the SEC has avoided pleading price artificiality to prove manipulation ${ }^{84}$ and, more notably, the reason the CFTC, in its 40-year history, has notched only a single successful prosecution of price manipulation. ${ }^{85}$

* $\quad * \quad *$

The above discussion of the relevant anti-manipulation provisions confirms the structural definitional requirements identified in Part I.B. Yet, in pursuing claims of open-market manipulation, the Commissions have ignored the requirement for harm, focusing exclusively on intent. Their approach has resulted in significant confusion and discord in the markets, as participants try to determine what constitutes open-market manipulation.

\section{UNDERSTANDING OPEN-MARKET MANIPULATION}

Open-market manipulation does not involve misstatements, fraud, fictitious trades, or deceit; the transactions are permissible and involve no objectively bad acts. ${ }^{86}$ In the absence of traditional forms of

82. The specific intent element is satisfied if the defendant "acted (or failed to act) with the purpose or conscious object of causing or effecting a price or price trend in the market that did not reflect the legitimate forces of supply and demand." Id.

83. See Anthony Candido, Freedom to Trade in the Age of Heightened Market Protection, HARV. L. SCH. F. ON CORP. GOVERnANCE \& FIN. REG. (Apr. 3, 2016), https://corpgov.law .harvard.edu/2016/04/03/freedom-to-trade-in-the-age-of-heightened-market-protection [https://perma.cc/794P-2CJ2] (summarizing CFTC's four-part test).

84. See Multer, supra note 15, at 115 (explaining that under Rule 10b-5, a trader can be held liable for market manipulation based on her intent).

85. In 2009, the CFTC prosecuted its first price manipulation case under the CEA - a victory after almost 30 years of the Commission's existence. See generally DiPlacido v. CFTC, 364 F. App'x 657 (2d Cir. 2009) (reviewing a CFTC decision on price manipulation and addressing issues of first impression within the case). This does not include the settlements for manipulation that the Commission has secured over the decades.

86. Abel Ramirez, Jr., Are Short Sellers Really the Enemy of Efficient Securities Markets? A Discussion of Misconceptions After the Financial Crisis, 42 SEC. REG. L.J. 31, 38 (2014) (noting that open-market manipulations are "accomplished by using entirely legitimate transactions, but [are] still subject to enforcement under Rule 10b-5 if the intended effect is 'a false pricing signal to the market." (citation omitted)). One scholar has described this distinction between traditional and open-market forms of manipulation as follows:

$[T]$ raditional manipulation involves conduct that is "inherently or otherwise illegal, such as fictitious transactions"... whereas open-market manipulation consists of facially legitimate transactions that make the fraud harder to detect. Claims of openmarket manipulation allege attempts to "increase the price of a security or commodity 
misconduct, the Commissions and private plaintiffs have alleged that open-market trades are manipulative because of the manipulative intent of the trader. ${ }^{87}$ This framing of open-market manipulation, however, does not articulate how the transactions harm the market, which is key to identifying manipulative activity.

Part II addresses the first question this Article poses: Can legitimate transactions distort the markets? To begin, this Part explores the mechanics of open-market manipulation, categorizing these schemes into two categories: naked and covered open-market manipulation. Using case studies, Part II demonstrates that traders can and do use open-market transactions to distort the market. Part II also highlights the inadequacies of the Commissions' intent-centric focus, given its inability to coherently articulate how open-market trades distort - that is, harm - the markets.

\section{A. The Mechanics of Open-Market Manipulation}

1. Typology: Naked and Covered Manipulation Schemes. Openmarket manipulation can be accomplished through naked or covered schemes. ${ }^{88}$ Both forms aim to profit from an asset's price movement, but each scheme accomplishes the goal differently. Naked openmarket manipulation schemes ("naked manipulation") distort the

by trading, and to sell at a profit before the price returns to its 'correct' level."

Tara E. Levens, Too Fast, Too Frequent? High-Frequency Trading and Securities Class Actions, 82 U. CHI. L. REV. 1511, 1515 (2015) (citations omitted).

87. Yesha Yadav, The Failure of Liability in Modern Markets, 102 VA. L. REV. 1031, 1053 (2016) ("The hallmark of actions to pursue fraud and manipulation lies in the requirement to show that defendants intended to lie or to deliberately alter prices in securities markets.... Authorities must adduce evidence of manipulative intention (scienter) to artificially distort price formation." (citation omitted)); see also Michael A. Asaro, 'Masri' and Open-Market Manipulation Schemes, 239 N.Y. L.J. ONLINE (2008), available at https://www.akingump.com/ images/content/1/2/v4/1243/07005080021AkinG.pdf [https://perma.cc/65YU-9TNU].

88. Some scholars refer to open-market manipulation broadly as trade-based manipulation. This author believes that the classification of open-market manipulation as naked or covered better aligns with and describes the conduct at issue. See Multer, supra note 15, at 97-98 ("Manipulative schemes are referred to as 'open market manipulations' when the alleged scheme is accomplished solely through the use of facially legitimate open market transactions. ... [It does not involve] any conduct that is inherently or otherwise illegal, such as fictitious transactions, wash sales or by disseminating false reporting."); Michael J. Aitken, Frederick H. deB. Harris \& Shan Ji, Trade-Based Manipulation and Market Efficiency: A Cross-Market Comparison 1(Nov. 18, 2009) (draft) (available at http://citeseerx.ist.psu.edu/viewdoc/download?doi= 10.1.1.629.2355\&rep=rep1\&type=pdf) [https://perma.cc/7XA5-Q2XC] (providing that "Allen and Gale (1992) define trade-based manipulation as a trader attempting to manipulate a stock price simply by buying and then selling (or vice versa), without releasing any false information or taking any other publicly observable action designed to alter the security's value"). 
market only through transactions. ${ }^{89}$ Any profit the manipulator earns from a naked manipulation scheme is from transactions executed on the open market. ${ }^{90}$ In short, the trader must buy the asset at a low price and be able to sell it at a high price. ${ }^{91}$ The trader, then, profits on the difference between the low purchase price and the high sale price. ${ }^{92}$ Naked manipulation is difficult because as the trader tries to buy low, her purchases will, in theory, increase the price of the asset. ${ }^{93}$ Likewise, as she tries to sell at the increased price, her sales will decrease the price. ${ }^{94}$ To be successful in a naked manipulation scheme, the trader must have some way of preventing the price from increasing as she purchases, decreasing as she sells, or both.

In covered open-market manipulation schemes ("covered manipulation"), on the other hand, a manipulator trades to trigger payments or rights in a separate contract or financial instrument, the pricing of which is affected by the trades. ${ }^{95}$ In short, covered manipulation involves open-market trades executed to impact the trader's interest in a separate, but related, obligation. A straightforward example is a company executive whose bonus is tied to the company's stock reaching a contractually established price threshold. Suppose the executive trades in her company's stock to exert

89. Nelemans, supra note 58, at 1169 ("Trade-based market manipulation . . is thought of as trading shares specifically to cause a price change.").

90. Fischel \& Ross, supra note 18, at 523 (stating that in "[t]hese schemes . . the trader's profit results directly from the trades").

91. Id. at 512 .

92. Id.

93. Jerry W. Markham, Commodities Regulation: Fraud, Manipulation \& Other Claims, 13 COMMODITIES REG. $§ 15: 3$ (Apr. 2018) (noting that traders have used manipulative maneuvers such as storing commodities to establish a scarcity and create favor for themselves, but that such maneuvers make it more difficult to "bury the corpse"); see also Rajesh K. Aggarwal \& Guojun Wu, Stock Market Manipulations, 79 J. Bus. 1915, 1916 (2006) ("[B]y purchasing a large amount of stock, a trader can drive the price up. If the trader can then sell shares and if the price does not adjust to the sales, then the trader can profit. Of course, we should expect that such a strategy would not work."); Jerry W. Markham, Manipulation of Commodity Futures Prices-The Unprosecutable Crime, 8 YALE J. REG. 281, 293 (1991) [hereinafter Markham, Manipulation] (explaining that someone who corners the market will need to "bury the corpse" - that is, dispose of the actual commodity used in the corner without significantly depressing prices - and that otherwise, she must forfeit the value of the corner).

94. Markham, Manipulation, supra note 93, at 293.

95. See, e.g., Fischel \& Ross, supra note 18, at 523 (describing what they call "contract-based manipulation," wherein "the trader's profit results from his ability to trigger a contractual right or benefit by trading. An example would be purchases by a corporate officer that raise the price of his firm's shares ... sufficient[ly] to trigger a bonus clause in his compensation package based on the firm's stock price"). 
upward pressure on its price. The increased stock price would trigger her bonus rights, and the executive would profit from her employment contract. The executive's conduct is an example of covered manipulation because of the connection between her trades and her contractual bonus payment.

Covered manipulation schemes are more complex and oftentimes use derivatives to profit from the price-moving effect of their trades. A derivative is a financial product that derives its value from the change in value of an underlying asset or from the occurrence of an external event. ${ }^{96}$ Derivatives allow traders to profit from an asset's changed value without the need to own the asset itself. Derivatives can be linked to equities; commodities, such as wheat, corn, or oil; or rates, such as foreign exchange rates or interest rates. ${ }^{97}$ Derivative instruments include forwards, futures, options, and swaps-each of which can be combined with additional features to increase their complexity and malleability. ${ }^{98}$ Derivatives have become commonplace in the financial markets and are useful tools for risk mitigation and exposure. ${ }^{99}$ An

96. William W. Bratton \& Adam J. Levitin, A Transactional Genealogy of Scandal: From Michael Milken to Enron to Goldman Sachs, 86 S. CAL. L. REV. 783, 815 (2013) ("[D]erivatives are contracts that specify payments based on the performance of external securities; the parties to the derivative need not own the securities referenced."); Gina-Gail S. Fletcher, Hazardous Hedging, supra note 5, at 824 ("A derivative is a financial instrument whose value derives from changes in the value of an underlying asset or external event, such as a rainfall, inflation, or a natural catastrophe." (citations omitted)); Lynn A. Stout, Derivatives and the Legal Origin of the 2008 Credit Crisis, 1 HARV. BUS. L. REV. 1, 6 (2011) ("Derivatives are literally bets-agreements between parties that one will pay the other a sum of money that is determined by whether or not a particular event occurs in the future.").

97. See generally Gina-Gail S. Fletcher, Benchmark Regulation, 102 IOWA L. REV. 1929 (2017) [hereinafter Fletcher, Benchmark Regulation] (discussing the intersection between benchmark manipulation and derivatives using interest rates, foreign exchange, and crude oil); Kimberly Amadeo, Derivatives, Their Risks and Their Rewards, BALANCE (May 1, 2018), https://www.thebalance.com/what-are-derivatives-3305833 [https://perma.cc/GVC7-2WJE] ("Derivatives are often used for commodities, such as oil, gasoline, or gold. Another asset class is currencies, often the U.S. dollar. There are derivatives based on stocks or bonds. Still others use interest rates, such as yield on the 10-year Treasury note.").

98. A forward is an obligation to buy or sell the underlying asset at a specified price on a future date. A future is a standardized forward that is traded on an exchange. An option is the right, but not the obligation, to buy or sell an asset on a specified date, at a specified price. And "[s]waps are agreements between two counterparties to exchange a series of cash payments for a stated period of time." Michael Chui, Derivative Markets, Products and Participants: An Overview, in 35 IFC Bulletins 5 (2012); Fletcher, Hazardous Hedging, supra note 96, at 825-26 (discussing that all derivatives have two foundational building blocks-options and forwards). See generally Fletcher, Benchmark Regulation, supra note 97 (discussing the use of derivatives in benchmark manipulation).

99. Anabtawi \& Schwarcz, supra note 46, at 1363 ("[F]irms can transfer credit risk through products such as swaps or other derivatives."). 
equity call option, for example, grants the purchaser the right to purchase a specified number of shares on a specified date. ${ }^{100} \mathrm{~A}$ call option is valuable if the trader believes that the equity's price will increase in the future. For example, suppose that a trader believes that Snap Inc.'s stock will rise once the company releases its quarterly earnings reports on March 31, 2018. Let us assume that today, Snap Inc. is trading at $\$ 14$ per share. The trader executes call options giving her the right to purchase 100 shares of Snap Inc. at $\$ 15$ per share on April 1, 2018-the strike date. If prior to the strike date, the value of Snap Inc.'s stock rises to $\$ 20$ per share, then the options are "in the money," that is, profitable. The trader would exercise her options and earn a profit of $\$ 500$. If, however, Snap Inc.'s shares do not go above $\$ 15$ per share, the options are "out the money," and the options would expire, worthless. Derivatives, therefore, are inextricably bound to both the commodities and futures markets, as their valuation is directly linked to the assets on which they are based.

Covered manipulation schemes exploit the connection between derivatives, on the one hand, and the commodities or securities - or both - markets, on the other, by trading in the latter to affect the price of the former. To continue with the equity call option example above, assume that as the strike date approaches, Snap Inc.'s stock does not rise above $\$ 15$ per share. Not wanting her options to expire out the money, the trader enters the market and purchases a large number of Snap Inc. shares, pushing the price upwards. The upward price pressure changes the profitability of her options contract, which in the absence of her open market trades, would have been worthless. Importantly, in contrast to a naked manipulation scheme, the trader in this coveredmanipulation scheme does not need to sell her Snap Inc. shares to benefit. If she successfully exerts upward pressure on Snap Inc.'s shares, her options would be in the money and profitable, without her ever selling shares on the market. Derivatives, therefore, enable manipulators to avoid the market forces that would limit or eliminate their ability to profit from open-market manipulation.

2. Common Strategies. Open-market manipulation schemes typically employ certain trading strategies to move the price of the

100. Tom Prieto, Tax Strategies for Long-Short Equity, 93 PRAC. TAX STRATEGIES 118, 120 (2014) ("One party to the equity option pays a premium to another party for the right, but not the obligation, to purchase or sell stock .... An equity call option is for the purchase of stock and an equity put option is for the sale of stock."). 
asset for the trader's benefit. These trading strategies are not per se impermissible, but they usually attract the attention of the Commissions and private plaintiffs as indicators of market manipulation. The two most common strategies implicated in allegations of open-market manipulation are "short selling" and "marking the close."

Generally, traders short sell a security if they believe its price will decrease. ${ }^{101}$ In a security-based short sale, the trader borrows a security, sells the borrowed security, repurchases the security after the price has fallen, and then returns the borrowed security to its owner. ${ }^{102}$ The trader profits from the difference between the sale and purchase price, less any fees she paid to borrow the security. In the commodities market, a trader can achieve the same result with derivatives and without the need to borrow the underlying asset. For example, suppose a trader believes that an upcoming off-shore exploration will result in more oil being available, thereby reducing the price of oil in the upcoming month. She purchases 100 put options with a strike price of $\$ 75$, which give her the right to sell oil at $\$ 75$ per barrel before the expiration of the option. If the price of oil falls to $\$ 65$ per barrel, the trader is entitled to the difference between the market price and her strike price, less any fees paid to purchase the put option. ${ }^{103}$ Notably, the trader earns her profits without ever owning or borrowing a barrel of oil; through the put option she is able to gain exposure to the decrease in the price of oil without the additional expense of owning 100 barrels of oil.

Short selling is not illegal, although there are some who find the practice to be objectionable as a form of gambling. ${ }^{104}$ Aggressive or concerted short sales can exert price pressure on asset prices, and the Commissions and private plaintiffs have alleged this behavior to be manipulative. ${ }^{105}$ However, as some courts and lawmakers know, short

101. Short Sales, SEC, http://www.sec.gov/answers/shortsale.htm [https://perma.cc/8D6RZD95].

102. Id.; see also McCoy, Pavlov \& Wachter, supra note 33, at 1369 ("In a liquid market, investors are able to express their negative views by short selling, or by taking a long position if they believe there is possibility of appreciation. Through this process, fundamental market value is achieved.").

103. In this scenario, her gross profit would be $(\$ 75-\$ 65) \times 100=\$ 1000$.

104. See, e.g., James J. Angel \& Douglas M. McCabe, The Business Ethics of Short Selling and Naked Short Selling, 85 J. BUS. ETHICS 239, 243-44 (2009) (describing the short-and-distort campaigns involved with short selling as objectionable, while categorizing short selling as gambling).

105. See Sharette v. Credit Suisse Int'l, 127 F. Supp. 3d 60, 103 (S.D.N.Y. 2015) (finding 
sales can be beneficial to the markets by "contributing to efficient price discovery, mitigating market bubbles, increasing market liquidity, promoting capital formation, facilitating hedging and other risk management activities, and importantly, limiting upward market manipulations." ${ }^{106}$ The double-edged nature of short sales, therefore, makes it particularly important to identify when traders use the strategy maliciously, instead of beneficially.

Another strategy that some consider indicative of open-market manipulation is known as "marking the close" or "banging the close." This strategy involves making large transactions at or near the close of trading. ${ }^{107}$ End-of-day trading often has an outsized impact on asset pricing, thereby making trades done near the end of closing more effective in impacting the asset's price. ${ }^{108}$ Additionally, many derivatives are valued based on the end-of-day prices of the underlying asset, thus making the end-of-day price significant in calculating an instrument's value. ${ }^{109}$ The possibility, then, of changing the closing

manipulation where the plaintiffs were able to show that Credit Suisse drove down Energy Conversion Devices stock prices while short-sale prices significantly rose); GFL Advantage Fund, Ltd. v. Colkitt, 272 F.3d 189, 211 (3d Cir. 2001) (involving a defendant that alleged that GFL Advantage engaged in market manipulation by depressing stock prices through concentrated short sales).

106. Press Release, SEC, Statement of Securities and Exchange Commission Concerning Short Selling and Issuer Stock Repurchases (Oct. 1, 2008), http://www.sec.gov/news/press/2008/2008235.htm [https://perma.cc/TG77-V8W7].

107. The CFTC defines "banging the close" as:

A manipulative or disruptive trading practice whereby a trader buys or sells a large number of futures contracts during the closing period of a futures contract . . . in order to benefit an even larger position in an option, swap, or other derivative that is cash settled based on the futures settlement price on that day.

CFTC Glossary, CFTC, https://www.cftc.gov/ConsumerProtection/EducationCenter/ CFTCGlossary/glossary_b.html [https://perma.cc/3UH5-HUTN]; see also Alexander Osipovich, Bitcoin Futures Manipulation 101: How 'Banging the Close' Works, WALL ST. J. (Dec. 16, 2017, 7:00 AM), https://www.wsj.com/articles/bitcoin-futures-manipulation-101-how-banging-theclose-works-1513425600 [https://perma.cc/Z6BB-EWLL] (describing "banging the close" as a scenario that "involves pushing around the price of bitcoin when the futures contract expires").

108. See Carole Comerton-Forde \& Tālis J. Putniňš, Measuring Closing Price Manipulation, 20 J. FIN. INTERMEDIATION 135, 136 (2011) (finding that closing-price manipulation - that is, end-of-day trading-causes abnormal day-end returns that are approximately six times larger than their usual level and that significantly distorts prices, which is of great consequence due to the widespread use of closing prices).

109. As an example, suppose a trader holds a call option that gives her the right to purchase 100 barrels of oil at $\$ 75$ per barrel. A call option is the right to buy a security at a given price on the strike date. Call options are valuable if the option holder believes that the price of the asset will rise. Assume that the valuation of the trader's option - that is, the determination of the final price of oil-is linked to the market price on January 31, 2018. If on the strike date, the end-ofday price of oil is $\$ 80$ per barrel, she would profit on the spread $-\$ 5$ per barrel. 
price of an asset can be quite valuable to covered manipulation schemes. However, high volume end-of-day trading is not per se manipulative, and there are legitimate reasons for these types of transactions. ${ }^{110}$ Studies have shown that trading in the securities markets is heaviest just before the close of the market because traders monitor market activity and their positions throughout the day before executing their trades. ${ }^{111}$ Because of the benefits and drawbacks associated with this strategy, it is necessary to find a way to delineate between traders who execute trades at the end of the day to manipulate the market and those who do so for legitimate reasons. Otherwise, the markets will operate inefficiently.

\section{B. Manipulating Openly: Case Studies}

A fundamental issue concerning open-market manipulation is whether it is feasible-both on a theoretical and practical level. Theoretically, that the defendant is executing permissible trades raises the question of whether market manipulation can exist without misconduct. Practically, the legitimacy of the transactions seems to immunize them from regulatory inquiry. But legitimate, open-market transactions can distort the markets. The facial legitimacy of the transactions lulls one into believing that misconduct is absent and that the transactions are not acts of manipulation. As demonstrated in the four case studies below, the misconduct and market distortion stem from the negative impact the transactions have on the market, in addition to the manipulative intent of the defendant.

110. This possibility is not reflected in the SEC's settlement orders, which routinely find defendants guilty of market manipulation solely on the basis of marking the close. See, e.g., In re Kocherhans, Exchange Act Release No. 36556, 52 S.E.C. 528, 529 (Dec. 6, 1995) (involving a defendant who, over a 6-month period, made 47 purchases within 15 minutes of market close in the accounts of family members and customers in order to satisfy margin calls); In re Levin, Exchange Act Release No. 31124, 50 S.E.C. 1245, 1246 (Sept. 1, 1992) (involving a defendant who marked the close during 4 separate periods - ranging from 3 weeks to 2 months - on 2 exchanges in order to satisfy margin calls); In re Doherty, Exchange Act Release No. 29545, 50 S.E.C. 624, 626 (Aug. 12, 1991) (involving defendants who, for a period of four-and-a-half months, placed the final order of the day so that the closing price would be impacted by a higher ask price, which helped the defendants satisfy margin calls); In re Schaefer, Exchange Act Release No. 13736, 1977 S.E.C. LEXIS 1302, at *4 (July 11, 1977) (involving a defendant who successfully caused stock to close at a price higher than the prior sale price on approximately 253 out of 424 trading days in order to increase the value of the defendant's holdings).

111. Fischel \& Ross, supra note 18, at 520. 
1. Naked Price Control: Markowski v. SEC. Markowski v. SEC 112 presents a quintessential example of naked manipulation and aptly demonstrates that it is possible to manipulate the markets using facially legitimate transactions. In this case, Global America, Inc. ("Global") underwrote the initial public offering ("IPO") of Mountaintop Corporation. ${ }^{113}$ For six months thereafter, Global dominated the market for Mountaintop's securities, as the primary purchaser and seller, thereby keeping the price artificially high. ${ }^{114}$ Global's attempts to control Mountaintop's price ultimately failed, and, notably, once Global withdrew from the market, Mountaintop's securities declined by approximately 75 percent in a single day. ${ }^{115}$

It was undisputed that all the trades Global executed in Mountaintop's securities were permissible - they were real trades that did not involve deceit or misrepresentation. ${ }^{116}$ The SEC, however, argued that the defendants were guilty of market manipulation because of their intent. ${ }^{117}$ To bolster its claim of manipulative intent, the SEC highlighted (1) Global's dominance of the market for Mountaintop's securities $^{118}$ and (2) the fact that many of Global's clients invested in the IPO and would suffer significant losses if Mountaintop traded below its offering price. ${ }^{119}$ The D.C. Circuit agreed with the Commission, finding that the defendants' intent to manipulate the markets was sufficient, on its own, to hold them liable for market manipulation. ${ }^{120}$ Although the court's holding feels correct given the

112. Markowski v. SEC, 274 F.3d 525 (D.C. Cir. 2001)

113. Michael Markowski and Joseph Riccio Enjoined From Manipulating the Markets for the Securities of Three Companies, SEC NEws DIG., Mar. 4, 1996, at 1-2, https://www.sec.gov/ news/digest/1996/dig030496.pdf [https://perma.cc/C9Z3-HAKN].

114. See Brief for the Respondent in Opposition at 4, Markowski v. SEC, 537 U.S. 819 (2002) (No. 01-1749), https://www.justice.gov/sites/default/files/osg/briefs/2002/01/01/2001-1749.resp.pdf [https://perma.cc/GNU5-K5X8] (describing Global's after-market trading in Mountaintop's securities). According to the SEC, Global supported the price of Mountaintop's securities both by (1) maintaining high bid prices (that is, offers to buy) and (2) purchasing all unwanted securities and absorbing them into its inventory. Markowski, 274 F.3d at 527.

115. Markowski, 274 F.3d at 527. Indeed, Global's attempt at propping up Mountaintop's prices ultimately resulted in \$1.4 million in losses and the demise of Global. Id. at 527-29.

116. See id. at 528 ("Global's bids and trades in this case were 'real'-they involved real customers, real transactions, and real money ....").

117. See id. at 530 (presenting the SEC's position that Global purchased Mountaintop securities with the purpose of maintaining the security's apparent market price).

118. Id. at 527

119. See id. at 530 ("[A trader for Global] said that he maintained Global's bids because he feared a drop in price and the customer complaints it would generate.").

120. Id. 
havoc the defendants wreaked on the market, it is disconcerting that the sole stated basis for liability was the defendants' manipulative intent. A defendant's intent is salient to demonstrating the purposefulness of her actions, but intent is inadequate as an explanation of why otherwise legitimate transactions are manipulative.

2. Multiparty Scheme: United States v. Mulheren. United States v. Mulheren ${ }^{121}$ provides a poignant example of how covered manipulation may be accomplished through the coordinated efforts of multiple parties. John Mulheren, a market trader, and Ivan Boesky, a businessperson and banker, had a longstanding business relationship in which the two shared market information and trading tips. ${ }^{122}$ Boesky acquired 4.9 percent of the outstanding stock of Gulf \& Western Industries, Inc. ("G\&W") as the first step in a proposed leveraged buyout of the company. ${ }^{123}$ After G\&W rejected his acquisition offer, Boesky offered to sell his shares back to the company at $\$ 45$ per share, which was slightly above the current trading price of the company's stock. ${ }^{124} \mathrm{G} \& \mathrm{~W}$ stated that it was only willing to repurchase the shares at market price. ${ }^{125}$

The day after his conversation with G\&W, Boesky called Mulheren and stated, among other things, that "it would be great" if G\&W traded at $\$ 45$ per share. ${ }^{126}$ Shortly after his conversation with Boesky, Mulheren placed a series of purchase orders for a total of 75,000 shares of $\mathrm{G} \& \mathrm{~W}$, all within a 10-minute span. ${ }^{127}$ At the beginning of Mulheren's trading, G\&W traded at $\$ 44.75$; by the end of Mulheren's trading, G\&W shares traded at $\$ 45$ per share. ${ }^{128}$ Within minutes of G\&W's shares reaching $\$ 45$, Boesky sold his entire ownership stake back to $\mathrm{G} \& \mathrm{~W}$ at $\$ 45$ per share. ${ }^{129}$ At the end of trading

121. United States v. Mulheren, 938 F.2d 364 (2d Cir. 1991).

122. Id. at 366 .

123. Id. A leveraged buyout is the acquisition of another company, in which primarily debt is used to fund the cost of acquisition. See, e.g., Leveraged Buyout, BLACK'S LAW DICTIONARY (10th ed. 2014) (defining a leveraged buyout as "[t]he purchase of a publicly held corporation's outstanding stock by its management or outside investors, financed mainly with funds borrowed from investment bankers or brokers and usu. secured by the corporation's assets").

124. Mulheren, 938 F.2d at 366.

125. Id. at 367.

126. Id.

127. Id. at 367-68.

128. Id. at 368 .

129. Id. 
for the day, however, G\&W shares fell to $\$ 43.625$, and Mulheren's firm lost $\$ 64,406$ on his G\&W purchases. ${ }^{130}$ Notably, the decrease in G\&W's price was in stark contrast to the security's usual price change; the decrease represented a price variance over 10 times what was customary. ${ }^{131}$

The SEC charged Mulheren with market manipulation in violation of Rule 10b-5 on the basis that he intended to manipulate the markets when he purchased G\&W shares. ${ }^{132}$ Mulheren's concentrated purchase orders - executed after his conversation with Boesky-that caused G\&W's share price to increase were all indicative of an intent to manipulate, according to the SEC. ${ }^{133}$ The Second Circuit rejected the SEC's allegations, finding that the Commission did not prove Mulheren's subjective intent to manipulate, nor did the Commission prove that the transactions lacked an investment motive. ${ }^{134}$ Notably, in rejecting the SEC's manipulation claim, the Second Circuit seemed to be looking for anything akin to market harm-fictitious trades, fraud, or even an artificial price. ${ }^{135}$ By relying on manipulative intent, the SEC failed to demonstrate how and why Mulheren's transactions were manipulative, and, consequently, the Commission was unsuccessful. ${ }^{136}$

3. Last-Minute Trading: SEC v. Masri. SEC v. Masri ${ }^{137}$ presents another example of covered manipulation and, again, highlights the shortcomings inherent in the Commissions' intent-centric theory of liability. Moises Saba Masri was an active securities trader, typically making thousands of trades each year. ${ }^{138}$ Masri sold put options on over

130. Id.

131. Id. at 367-68 (indicating that between October 16, 1985, and October 17, 1985, G\&W stock moved from $\$ 44.75$ to $\$ 44.875$ and then to $\$ 45$ at different times of the day, but that on October 17, 1985, G\&W common stock closed at $\$ 43.625$ after the defendants sold a large amount of G\&W common stock). For a discussion of price volatility, see infra Part III.B.

132. See id. ("The government's theory of prosecution in this case is straightforward[:] ... [W]hen an investor, who is neither a fiduciary nor an insider, engages in securities transactions in the open market with the sole intent to affect the price of the security, the transaction is manipulative and violates Rule 10b-5.").

133. See id. at 369 (discussing the SEC's theories of Mulheren's manipulative intent).

134. Id.

135. See id. at 370-71 (stating that traditional indicia of manipulation are missing from the alleged manipulation scheme, such as fictitious trades, matched orders, wash sales, etc.).

136. See id. at 372 ("[I]n the absence of other indicia of manipulation - and there are nonethe fact that Mulheren dominated the market between 9:30 a.m. and 11:10 a.m. on October 17, 1985 . . carries little weight.”).

137. SEC v. Masri, 523 F. Supp. 2d 361 (S.D.N.Y. 2007).

138. Id. at 363 . 
800,000 shares of T.V. Azteca S.A. de C.V. American Depositary Receipts ("TZA") with a strike price of $\$ 5$ per share that expired on August 21, 1999..$^{139}$ As the exercise date approached, TZA share prices began to decline, approaching $\$ 5$ per share and eventually dropping below $\$ 5 .{ }^{140}$ On August 20, Masri purchased 200,000 shares of TZA stock in the last 10 minutes of trading, moving TZA's price from below $\$ 5$ to $\$ 5.125$ per share. ${ }^{141}$ Had TZA's shares remained below $\$ 5$, Masri would have been required to spend $\$ 4.3$ million to purchase the put options. ${ }^{142}$ Instead, in response to his blitzkrieg trading, TZA share price rose, and the options expired worthless, sparing Masri from incurring any losses. ${ }^{143}$ Notably, Masri's trades accounted for 94 percent of all TZA purchases in the last hour of trading and 75 percent for the day. ${ }^{144}$

In alleging that Masri was guilty of open-market manipulation, the SEC inferred Masri's manipulative intent from the "timing, size, and incremental execution" of the trades, among other things. ${ }^{145}$ Masri asserted that his trades were economically rational and were motivated by other unexpired options he held on TZA stock. ${ }^{146}$ After a careful analysis of the matter, the court held that liability for open-market transactions can be imposed if the plaintiff proves that "but for the manipulative intent, the defendant would not have conducted the transaction." 147 The court recognized Masri's explanation for his trades as plausible but refused to grant his motion to dismiss because the SEC's evidence of intent, albeit weak, was sufficient. ${ }^{148}$ Interestingly, although speaking in the language of "manipulative intent," the court was in search of evidence that Masri's conduct harmed the market by

139. Id. at 363-65. A put option gives the holder the right, but not obligation, to purchase the underlying asset at the strike price on the agreed-upon date (known as the strike or exercise date). See Fletcher, Hazardous Hedging, supra note 5, at 825 (defining an option). In this case, Masri sold put options on TZA, which meant that if the buyer of the put option chose, Masri would be obligated to buy TZA shares at five dollars per share on the strike date. As the put seller, Masri expected the price of TZA to increase. If the price of TZA fell below five dollars per share, Masri would be obligated to pay more for the shares than its market price.

140. Masri, 523 F. Supp. 2d at 364-66.

141. Id.

142. Id. at 366 .

143. Id. at $365-66$.

144. Id. at 365 .

145. Id. at 373 .

146. Id. at $373-75$.

147. Id. at 372 .

148. Id. at 375 . 
“'artificially' affecting the price of the security or injecting inaccurate information into the market." ${ }^{149}$ In the absence of evidence of harm to the market or other market participants, the court was unwilling to impose liability, despite the defendant's admittedly suspicious conduct. ${ }^{150}$

4. Guaranteed Profits: CFTC v. Amaranth Advisors. CFTC v. Amaranth Advisors ${ }^{151}$ is a case in which the government successfully held the defendants liable for open-market manipulation. As part of an archetypal covered manipulation scheme, the Amaranth defendants executed open-market trades to ensure the profitability of related derivatives. ${ }^{152}$ Amaranth Advisors ("Amaranth") was a hedge fund, specializing in natural gas trading, that had approximately $\$ 9$ billion of assets under management. ${ }^{153}$ On two separate occasions in February and April 2006, Amaranth accumulated a substantial number of gas futures contracts that traded on the New York Mercantile Exchange ("NYMEX"). ${ }^{154}$ On the final day of trading, during the last 30 minutes, Amaranth flooded the NYMEX natural gas markets with offers to sell its gas futures. ${ }^{155}$ In the last 4 minutes of trading, Amaranth was responsible for 99 percent of all trading in the asset. ${ }^{156}$ Amaranth also held a large position in natural gas swaps. ${ }^{157}$ The profitability of Amaranth's swaps depended on the decrease of natural gas prices on the NYMEX. ${ }^{158}$ In sum, Amaranth marked the close on the NYMEX gas futures which benefitted its position on natural gas swaps that were valued by reference to the NYMEX gas closing price.

The CFTC charged Amaranth and its principal trader, Brian Hunter, with attempted price manipulation. ${ }^{159}$ Relying on Hunter's text

149. Id. at 373 .

150. Id. at 375 .

151. CFTC v. Amaranth Advisors, L.L.C., 554 F. Supp. 2 d 523 (S.D.N.Y. 2008).

152. Id. at 525 .

153. Lloyd Dixon, Noreen Clancy \& Krishna B. Kumar, Hedge Funds And SYSTEMIC RISK 34 n.10 (2012).

154. Amaranth, 554 F. Supp. $2 \mathrm{~d}$ at 530.

155. Id. at 527 ("Less than half an hour before the closing range, Hunter disclosed his trading strategy to another trader....").

156. See id.

157. A commodity swap is a derivative "in which the payout to at least one counterparty is based on the price of a commodity or the level of a commodity index." Id. (citation omitted).

158. Id. at 528 .

159. The CFTC did not have the authority to bring non-price-manipulation cases in 2006. Id. at 525 . 
messages in which he articulated a clear intent to manipulate the NYMEX, the CFTC was able to easily demonstrate manipulative intent. ${ }^{160}$ Importantly, the CFTC also provided evidence of how the transactions undermined the markets, which was key to the Commission's successful prosecution. In light of the defendants' stated manipulative intent and the evidence of market injury, the court found Amaranth and Hunter guilty of market manipulation. ${ }^{161}$ In its analysis, the court focused on the fact that Hunter's trades disrupted the markets because the deluge of last-minute orders could not be filled before the close of trade. ${ }^{162}$ The court also noted that Amaranth improperly favored its swaps' profitability by marking the close to depress the NYMEX closing price. ${ }^{163}$ In sum, Amaranth's conduct was manipulative because the defendants possessed the intent to manipulate and because their trades injured the markets and exploited their counterparties.

Importantly, Amaranth highlights the need for analytical clarity, particularly in instances of open-market manipulation. The court said it was only looking at manipulative intent and overt acts, regardless of the legality of the acts. Yet, the court's analysis considered the impact of the defendant's transactions on the market. The court's and the CFTC's approach here is laudable because it considered the impact of the defendants' conduct on the market in deciding whether the legitimate transactions were manipulative. However, conflating the analysis of intent with that of market impact exacerbates the confusion over what the law requires before a trader may be held liable for openmarket manipulation.

Market manipulation is feasible through open-market transactions, as demonstrated from the case studies above. The Commissions and private parties have achieved varying degrees of success in proving that, mostly because of their singular focus on the intent of the trader as the basis of liability. In relying solely on intent, plaintiffs limit their ability to hold perpetrators accountable for openmarket manipulation because intent does not explain why facially

\footnotetext{
160. Id. at 532-33.

161. Id.

162. Id.

163. Id. at 528 .
} 
legitimate transactions are manipulative. ${ }^{164}$ As analyzed in greater detail in Part II.C, below, the intent-centric theory of liability is incomplete, and it is an insufficient regulatory tool in combatting openmarket manipulation.

\section{The Insufficiency of Intent}

The practical and conceptual difficulties inherent in open-market manipulation make it tempting to rely on the "know it when you see it" standard. ${ }^{165}$ In some ways, reliance on intent seems to adopt such a measure, but this approach does not make it clear to the markets when legitimate conduct may result in liability. Under the current approach to open-market manipulation, intent plays an outsized role in determining liability; this enforcement approach neither makes the markets safer nor adequately proscribes open-market manipulation. The exclusive reliance on intent short-circuits lawmakers' attempts to curb, and plaintiffs attempts to successfully prosecute, open-market manipulation because (1) intent is both over- and underinclusive and (2) intent does not explain how or why legitimate transactions distort the markets.

1. Scope of intent. The scope of the intent-centric approach to open-market manipulation is both too broad and too narrow, making it ineffective in combatting market manipulation. It is underinclusive because of the inherent difficulty of proving intent. ${ }^{166}$ Rarely is direct evidence of a defendant's manipulative intent available. In the financial industry, it is even less likely that such proof would be available because of the disinclination of members of highly regulated industries to commit incriminating information to writing. ${ }^{167}$ Absent

164. Lisa M. Fairfax, Sarbanes-Oxley, Corporate Federalism, and the Declining Significance of Federal Reforms on State Director Independence Standards, 31 OHIO N.U. L. REV. 381, 383, 392 (2005) (explaining that corporate directors' independence is important to corporate accountability, and that shareholder derivative suits generally allege a breach of fiduciary duty).

165. See Jacobellis v. Ohio, 378 U.S. 184, 197 (1964) (Stewart, J., concurring) (setting the standard for pornography as "I know it when I see it").

166. See Huang, supra note 18 , at 6 ("[T] he difficulty of proving the intent requirement is [a] ... main reason[] for the introduction of civil penalties to the market manipulation regime in the 2001 [Australian securities law] reform. It had [previously] been argued . . . that intention was too difficult to prove and this had impeded successful market manipulation prosecutions." (citation omitted)); cf. Loke, supra note 18, at 21 ("There is much that is problematic with Fischel and Ross' thesis. While there is some truth to the notion that 'it is extremely difficult to discern the intent of a trader with objective evidence', objective evidence does not consist merely of the impact of the trade.").

167. This is not always the case. In the Amaranth case discussed supra Part II.B.4, the 
explicit or direct proof of a trader's intent to manipulate, plaintiffs and fact finders must infer intent from circumstantial evidence. Plaintiffs routinely rely on trading patterns such as trade size, volume, and timing. ${ }^{168}$ Yet, given the permissibility of traders' actions in cases of open-market manipulation, these factors are all subject to interpretation. ${ }^{169}$

The evidentiary burden associated with intent is further increased by the ability of traders to explain their legitimate transactions in a nonmanipulative manner, particularly ex post. ${ }^{170}$ Courts are likely to err on the side of caution when interpreting equivocal evidence of manipulative intent in open-market manipulation cases, particularly in the absence of market harm. ${ }^{171}$ Indeed, the intent-alone-is-enough standard may increase the difficulty of proving open-market manipulation, to the detriment of the wider markets. The legitimacy of the trades, the ambiguity of the evidence of intent, and the reluctance of the courts to base liability solely on intent all combine to decrease the likelihood of successfully proving open-market manipulation under this standard. Hinging the provability of manipulation solely on intent means that most instances of manipulation will go unpunished. The problematic nature of intent, therefore, hampers regulators' ability to adequately address this form of manipulation, effectively leaving abusive market behavior unchecked.

Conversely, the intent standard is overinclusive because it includes transactions for which the trader had a manipulative intent, but which did not harm the market. A trader, for example, may execute trades, hoping and wishing that they create a momentary distortion in

defendant provided emails and instant messages to the CFTC as part of the agency's investigation. Defendant's Memorandum of Law in Support of Motion to Dismiss at 3, CFTC v. Amaranth Advisors, L.L.C., 554 F. Supp. 2d 523 (S.D.N.Y. 2007) (No. 07 Civ. 6682 (DC)), 2007 WL 4403879.

168. SEC v. Masri, 523 F. Supp. 2d 361, 369 (S.D.N.Y. 2007) (explaining that open-market manipulation allegations often include transactions with suspicious timing, high volume, or a pattern of prior manipulation).

169. Indeed, what plaintiffs consider to be evidence of manipulative intent may be construed as a defendant's unbridled exuberance. See, e.g., Markowski v. SEC, 274 F.3d 525, 528 (D.C. Cir. 2001) ("It may be hard to separate a 'manipulative' investor from one who is simply overenthusiastic, a true believer in the object of investment.").

170. See, e.g., Masri, 523 F. Supp. 2d at 372-74 (involving a defendant who provided ex post explanations for his suspicious transactions to justify them as legitimate, nonmanipulative trades).

171. See generally ATSI Commc'ns, Inc. v. Shaar Fund, Ltd., 493 F.3d 87 (2d Cir. 2007) (dismissing the plaintiff's complaint that the defendants were manipulating the price of its common stock by converting preferred stock into common stock, since the complaint's lack of a connection between the stock price and the defendants' actions constituted a failure to adequately plead the scienter requirement). 
price. Despite her intentions and her legitimate transactions, however, suppose that she fails to manipulate the market. Per the Commissions' approach, such conduct still constitutes market manipulation because of the trader's intent. Yet, in this scenario, no matter how explicit the intent of the trader, if her trades did not harm the market, she should not be liable for market manipulation. Admittedly, this is an extreme example, but it demonstrates that imposing liability exclusively on the basis of the intent of the trader can have inappropriate results that do not improve the markets.

Furthermore, the overbroad nature of the intent standard can have a chilling effect on beneficial market conduct. A component of market liquidity is the existence of traders who hold different beliefs about the price of an asset or the future trajectory of the markets. ${ }^{172}$ Traders' ability to express their divergent opinions through their transactions is essential to establishing an equilibrium in the markets and fostering market liquidity, both of which contribute to market efficiency. ${ }^{173}$ Grounding claims of manipulation solely on intent, particularly when the proof is circumstantial, may deter traders from engaging in beneficial market activity out of fear of liability. Traders may exit the markets to avoid penalization for their legitimate transactions that, ex post, may be construed as manipulative-a net negative result for the markets.

2. Intent is not harm. The intent to manipulate is a crucial aspect of imposing liability for open-market manipulation, ${ }^{174}$ but alone, intent is an incomplete basis. A trader's manipulative intent is important in proving that her conduct was not accidental or negligent and, as such, that the trader is blameworthy. The legitimacy of the transactions in open-market manipulation schemes does not render the trader's behavior immune from liability; however, it must be demonstrated that her conduct caused harm. Otherwise, the trader would be punished for her bad intent alone. This defies basic criminal law theory that one is

172. See Laura E. Hughes, The Impact of Insider Trading Regulations on Stock Market Efficiency: A Critique of the Law and Economics Debate and a Cross-Country Comparison, 23 TEMP. INT'L \& COMP. L.J. 479, 495 (2009) (explaining that in a liquid market, shares are bought and sold easily, but that in an illiquid market, a seller might be unable to sell a stock since all buyers believe that the price is unfairly low or that it would be irrational to sell the stock).

173. Global Financial Markets Liquidity Study, PWC (Aug. 2015), https://www.pwc.se/sv/pdfreports/global-financial-markets-liquidity-study.pdf [https://perma.cc/X9X9-46NP].

174. Multer, supra note 15, at 106 (explaining the role of intent in cases of open-market manipulation). 
not punished merely for a criminal state of mind, but that one's actions must be criminal as well to warrant punishment. ${ }^{175}$ The intent to manipulate without proof of market harm-such as injury to the proper functioning of the markets - is an inadequate basis for liability.

An exclusive focus on manipulative intent conflates scienter with misconduct. For some acts, bad intent transforms otherwise legitimate conduct into criminal conduct. ${ }^{176}$ For example, if someone follows another person innocently because they happen to be going in the same direction, this is not a criminal act. But if someone follows another with the intent to harm or intimidate them, this is stalking. In transforming otherwise legal behavior into a criminal act, the intent and the effect of the actor's conduct are important. The same must be true for openmarket manipulation. Both the intent of the trader's behavior and the effect her conduct has on the market are necessary if facially legitimate transactions are to be found manipulative. This comports with the purpose of anti-manipulation laws-to protect the markets from abusive behavior because it undermines the proper functioning of the markets. A cogent theory of open-market manipulation must frame liability in terms of the intentionality of the trader's conduct and the negative impact the conduct has on the market.

In sum, intent is an insufficient basis for delineating between legitimate transactions and manipulative transactions. Intent is also an insufficient basis for protecting the markets from open-market manipulation. Alone, intent neither provides a coherent basis for liability, nor effectively punishes open-market manipulation. Including harm in the liability analysis is the most effective mechanism for classifying a transaction as manipulative, despite its being facially legitimate.

175. John M. Darley \& Thane S. Pittman, The Psychology of Compensatory and Retributive Justice, 7 PERSONAlity \& SOC. PSYCHOL. REV. 324, 325 (2003) (arguing that the defendant's punishment should be proportional to "the wrongness of their actions in inflicting the original harm").

176. See Daniel Waldman, Has the Law of Manipulation Lost Its Moorings, MondAQ (Apr. 7, 2017, 3:50 PM), http://www.mondaq.com/unitedstates/x/585174/Commodities+Derivatives +Stock+Exchanges/Has+The+Law+Of+Manipulation+Lost+Its+Moorings [https://perma.cc/ HBQ7-YU3E] (describing intent as paramount to a manipulation charge because "absent conduct that is fraudulent or by its very nature price-distorting, "it is the intent of the parties which separates otherwise lawful business conduct from unlawful manipulative activity" (citation omitted)); see also Langevoort, supra note 56, at 4 (noting that while intent is a debated term, with respect to trading, "scienter means that the insider must have deliberately taken advantage of - that is, used-the information for personal gain," and that the "bad act" is stripped of its intentionality absent proof of scienter). 


\section{A HARM-BASED APPROACH}

In light of the feasibility of open-market manipulation and the shortcomings of the intent-centric approach, Part III turns to the second question this Article poses: On what basis can legitimate transactions be considered manipulative? As alluded to above, liability for open-market manipulation ought to require proof of the trader's manipulative intent and the harm her transactions imposed on the market. Part III begins by analyzing the importance of including market impact in analysis of open-market manipulation. This Part goes on to analyze how open-market manipulation undermines the goals of anti-manipulation laws and regulations by impairing market efficiency and integrity. Part III also considers whether there is a role for market discipline in proscribing and punishing open-market manipulation. Finally, Part III puts forward suggestions to improve the detection and enforcement of open-market manipulation.

\section{A. Why Harm Matters}

The Commissions, courts, and plaintiffs have struggled to identify open-market manipulation because they fail to intellectually wrestle with whether and how facially legitimate transactions harm the market. Harm is a necessary component for determining whether legitimate transactions are, in fact, illegal acts of market manipulation. By not engaging with the question of how open-market manipulation harms the market, lawmakers risk going beyond their stated goals, needlessly interfering with the markets, and chilling socially beneficial conduct. Identifying how trades harm the markets requires thinking about harm not only in terms of affirmative conduct, but also as market impact. ${ }^{177}$ A trader who deliberately executes facially legitimate transactions that negatively affect the markets is as responsible for her actions as someone who issues a fraudulent statement to affect the price of an asset. In both instances, the trader's conduct harms the market, but because the former uses legitimate transactions, some courts do not impose liability. Traders ought to be held responsible for the impact of their conduct on the markets, regardless of the methodologies they used. This Article's proposed harm-based analysis provides a basis for

177. Stephen J. Choi, Selective Disclosures in the Public Capital Markets, 35 U.C. DAVIS L. REV. 533, 551 (2002) ("To the extent the market price reacts to the recommendations of [rating] analysts, the ability to engage in selective disclosures may therefore affirmatively reduce the accuracy of stock market prices." (citation omitted)). These inaccurate stock prices harm the efficiency and liquidity of the market. 
alleging misconduct based on the negative impact the transactions had on the markets.

In determining whether legitimate transactions injure the markets, vague notions of harm do not suffice. Rather, reference must be made to the goals of anti-manipulation laws. Specifically, to the extent that legitimate trades impair market efficiency and market integrity and are executed with the requisite manipulative intent, they ought to be deemed manipulative from a legal standpoint because they are functionally the same as traditional forms of manipulation. Failure to punish such behavior has perverse results on the markets because it encourages traders to aim for the same market impact but allows them to avoid liability if their manipulative acts are legitimate transactions. However, just as harm is necessary for liability, so is intent. Openmarket trades that harm the market despite being done without the requisite intent ought not be punished. Negligent trading that impairs the markets' efficiency is not market manipulation, and failure to hold a trader liable in such cases would likely not impede market integrity. ${ }^{178}$

A harm-based approach, which requires both manipulative intent and market harm, treats the legitimacy of the trades for what it is - a distraction. This approach seriously engages with the negative impact that permissible conduct can have on the market. Including harm in the analysis, therefore, provides a cogent framework through which one can be held liable for open-market transactions that manipulate the markets.

\section{B. Identifying Harm to the Markets}

Open-market manipulation harms both market efficiency and market integrity. This Section analyzes how legitimate transactions may nonetheless distort market prices, and it highlights specific market conditions that may enable a trader to commit open-market manipulation. This Section also analyzes how open-market manipulation causes the markets to be unfair, thereby weakening market integrity, and it discusses the contours of unjust wealth transfers as a basis of liability.

1. Market Efficiency. The most obvious harm open-market manipulation schemes may inflict on the markets is the impairment of

178. The markets are not risk free. Mistakes are possible; if trading that harms the market is merely the result of a mistake or negligence, liability for market manipulation should not be imposed. 
market efficiency. Market actors expect to execute trades at prices that are undistorted, even if not necessarily accurate, reflections of the current economic value and future-earnings expectations of the asset. ${ }^{179}$ Traders can use open-market transactions to weaken market efficiency by creating an artificial price for an asset. ${ }^{180}$ The facially legitimate nature of the transactions in open-market manipulation seems incongruous with a claim of price distortion. This is not correct; even with legitimate transactions, asset prices may be made artificial. As seen in the case studies, facially legitimate trades may be used to interfere with the markets' pricing ability, thereby contributing to a distorted price. To the extent that a trader's conduct distorts market pricing, her transactions harm market efficiency and, consequently, are manipulative.

Key to understanding how open-market trades can create an artificial price is disabusing oneself of the notion that price artificiality requires illegal conduct. To equate artificiality with illegality is to needlessly circumscribe the types of behavior that distort the market. ${ }^{181}$ There are two prevailing approaches to identifying price artificiality. One approach views an artificial price as one that is not established by the forces of supply and demand. ${ }^{182}$ The phrase "supply and demand"

179. SEC v. Masri, 523 F. Supp. 2d 361, 371 (S.D.N.Y. 2007) ("[T]he purpose of securities law [is] to 'prevent practices that impair the function of stock markets in enabling people to buy and sell securities at prices that reflect undistorted (though not necessarily accurate) estimates of the underlying economic value of the securities traded." (citing In re Global Crossing Ltd. Sec. Litig., 322 F. Supp. 2d 319, 337 (S.D.N.Y. 2004))).

180. Supra Part II.

181. Charles Mills \& Karen Dildei, The Necessity of Price Artificiality in Manipulation and Attempted Manipulation Claims, 37 FUTURE \& DerIVATIVES L. REP. 1, 8 (2017) ("As the CFTC stated, "when a price is effected by a factor which is not legitimate, the resulting price is necessarily artificial. Thus, the focus should not be as much on the ultimate price, as on the nature of the factors causing them." (citation omitted)).

182. Rosa M. Abrantes-Metz, Gabriel Rauterberg \& Andrew Verstein, Revolution in Manipulation Law: The New CFTC Rules and the Urgent Need for Economic and Empirical Analyses, 15 U. PA. J. BUS. L. 357, 370 (2013) ("An artificial price is one that does not "reflect basic forces of supply and demand."'(citation omitted)); Benjamin E. Kozinn, The Great Copper Caper: Is Market Manipulation Really a Problem in the Wake of the Sumitomo Debacle?, 69 FORDHAM L. REV. 243, 261 (2000) ("[A] price is artificial when it "does not reflect the market or economic forces of supply and demand ...." (citation omitted)); Mills \& Dildei, supra note 181, at 4 (explaining that price artificiality conveys that the market does "not reflect the legitimate forces of supply and demand" (citation omitted)); Wendy Collins Perdue, Manipulation of Futures Markets: Redefining the Offense, 56 FORDHAM L. REV. 345, 370 (1987) ("Another approach defines artificial price as a price that does not reflect the 'basic' or 'legitimate' forces of supply and demand." (citation omitted)); Colleen Powers, Note, Filling the Regulatory Void in the FX Spot Market: How Traders Rigged the Biggest Market in the World, 43 FORDHAM URB. L.J. 139, 163 (2016) ("An artificial price is one that does not 'reflect basic forces of supply and 
refers not only to the aggregate manifestations of the market, but also to other market factors, including general market expectations about the price of the asset, unexpected external events such as natural disasters or changes to government policy, and historical market behavior, among other things. ${ }^{183}$ The second definitional approach to price artificiality considers whether the price deviates from the historical, expected price of the asset. ${ }^{184}$ In determining whether a price is distorted, courts consider the dollar price, the spread between the cash and futures markets, or the spread in the markets from one month to the next. ${ }^{185}$

Determining whether a price is artificial requires detailed econometric analysis that is beyond the scope of this Article. ${ }^{186}$ As such, this Article accepts both definitions of price artificiality, since their

demand." (citation omitted)). This definition of price artificiality is not without its critics. See, e.g., Frank H. Easterbrook, Monopoly, Manipulation, and the Regulation of Futures Markets, 59 J. Bus. S103, S117 (1986) (“An effort to isolate which 'forces of supply and demand' are 'basic' and which are not is doomed to failure.").

183. See MARK LOVEWELL, UNDERSTANDING ECONOMICS: A CONTEMPORARY PERSPECTIVE 35 (6th ed. 2012) ("The five main demand factors are the number of buyers in a market, their average income, the prices of other products, consumer preferences, and consumer expectations about future prices and incomes."); $i d$. at 40 ("The six main supply factors are the number of producers, resource prices, the state of technology, changes in nature, the prices of related products, and producer expectations. Once again, with each factor, we must assume that all other factors remain constant."); see also Robert B. Thompson, Market Makers and Vampire Squid: Regulating Securities Markets After the Financial Meltdown, 89 WASH. U. L. REV. 323, 342 (2011) (noting that investors' expectations distort trading interactions and increase risk involved in transactions, which generally shifts the supply and demand curve).

184. Perdue, supra note 182, at 367 ("[A]n artificial price is one that is historically unusual, either because of its absolute level or because of its relationship to other prices.").

185. Cargill, Inc. v. Hardin, 452 F.2d 1154, 1167-70 (8th Cir. 1971) (accepting the Government's three tests for establishing price distortion in the wheat futures market: (1) a record increase in price of the future by 18.625 cents, (2) the spread between the May and July wheat futures in 1963 experienced a record increase compared to the previous nine years, and (3) "the May 1963 futures price was considerably out of line with the Kansas City futures price as compared with these prior years"). From a practical and theoretical standpoint, assessing the "normal" price is an inquiry plagued with difficulties. Indeed, because of the scope of this question, methodology is limited (1) to those instances in which manipulation causes a change in price that is significant enough to deviate from historical patterns, and (2) to those assets that have a long history of being heavily traded. See David B. Kramer, The Way It Is and the Way It Should Be: Liability Under $\$ 10(b)$ of the Exchange Act and Rule 10b-5 Thereunder for Making False and Misleading Statements as Part of a Scheme to "Pump and Dump" a Stock, 13 U. MiAMI BUS. L. REV. 243, 296 (2005) ("[T]hose stocks that are heavily traded . . are less likely to be affected by such misleading or false information. This is due to the fact that the market quickly corrects itself due to the large number of investors and the vast amount of coverage such stocks receive.").

186. See Abrantes-Metz, Rauterberg \& Verstein, supra note 182, at 357 (proposing the use of econometric screens to determine price artificiality). 
difference is only in mechanics, not in substance. As the case studies above demonstrate, it is possible to create an artificial price via legitimate transactions. The case studies also highlight factors that oftentimes indicate that a price may be distorted instead of being the product of the natural forces of supply and demand. The three primary market conditions that may suggest that facially legitimate trades are being used to distort asset prices are (1) market domination, (2) market volatility, and (3) market illiquidity. The existence of any of these factors, whether singularly or collectively, is not per se proof that a price is artificial. Rather, their presence should increase scrutiny of the legitimacy of the transactions, with the aim of determining whether the transactions contributed to or caused a distorted price and were, therefore, manipulative.

a. Market Domination. One indicator of whether facially legitimate trades created an artificial price is the level of control the trader has over the market. ${ }^{187}$ Market control occurs when a trader or traders working together acquire a monopoly stake, or a close approximation, in the supply or demand of physical commodities, securities, or other financial contracts. ${ }^{188}$ The trader, then, can use her market power to dictate the price of the asset. ${ }^{189}$ Possessing a controlling position in an asset is not per se illegal, and indeed there are instances in which an entity holds a natural monopoly position in a market. ${ }^{190}$ The issue, therefore, is not merely possession of a controlling

187. See Candido, supra note 83 ("Economic theory ... holds that purchases or sales in a free market will in general have an impact on market price through the natural forces of supply and demand. Thus, price influence can be anticipated from an economic standpoint.”). The Candido piece also provides that:

a trader who holds positions in both the futures and physical markets may abstain from trading in either or both markets to avoid being accused of trading to affect price. Or, a trader who believes prices are low may abstain from taking advantage of this pricing inefficiency by trying to buy as much as possible due to a fear of influencing the price.

Id.

188. AvgOULEAS, supra note 47 , at $147-48$.

189. Id.

190. Id.; see also Paul L. Joskow, Regulation of Natural Monopoly, in 2 HANDBOOK OF LAW AND ECONOMICS 1227, 1232 (A. Mitchell Polinsky \& Stevan Shavell eds., 2007) (defining a natural monopoly as "a firm producing a single homogeneous product . . . when it is less costly to produce any level of output of this product within a single firm than with two or more firms"). Richard Posner also helpfully defines the natural monopoly:

If the entire demand within a relevant market can be satisfied at lowest cost by one firm rather than by two or more, the market is a natural monopoly, whatever the actual number of firms in it. If such a market contains more than one firm, either the firms will quickly shake down to one through mergers or failures, or production will continue to consume more resources than necessary. 
position, but whether the trader used her position to dictate pricethat is, to corner or "squeeze" the market. ${ }^{191}$ A trader that acquires market control through open-market transactions and abuses her power to distort the market is liable for manipulation, despite the legitimacy of the underlying transactions. Asset pricing that is the result of a cornered market is not market driven and is, therefore, artificial.

Taking price artificiality seriously as an avenue for liability for open-market manipulation allows us to reframe instances of openmarket manipulation in terms of the trader's domination of the market and the impact that control had on the asset's price. When considered as such, the harm the facially legitimate transactions had on the market is evident - the transactions were used to fix prices that did not reflect the market-driven forces of supply and demand. The Markowski case, discussed above, provides a salient example. The defendants controlled the market, and using their control, they established an artificially inflated price for the security ${ }^{192}$ The legitimacy of the transactions, in such cases, are red herrings that distract from the defendants' abuse of their market power to distort securities prices. To the extent that traders utilize their market position to dictate asset prices, there should be a strong inference that they have manipulated the markets.

Price distortion is possible even if the trader's domination of the market is short-lived. Traditionally, courts have been reluctant to recognize market power that has not been maintained over a period of weeks or months. ${ }^{193}$ In today's markets, in which assets are owned for mere seconds, market control may be established in a shorter time

Richard A. Posner, Natural Monopoly and Its Regulation, 21 STAN. L. REV. 548, 548 (1969).

191. U.S. courts have identified four main criteria of market power manipulations: (a) the existence of a dominant or merely controlling position in deliverable supplies; (b) the existence of a dominant or merely controlling position in the futures market for a specific delivery period; (c) whether these positions have been built up with manipulative intent; and (d) whether they [have distorted] prices in both markets." AvgOULEAs, supra note 47, at 148. Professor Lin explains the difference between corning and squeezing:

Cornering generally occurs when one or more parties acquire the total supply of a financial instrument or commodity and then dictate the market prices of that instrument or commodity, thereby manipulating natural price discovery of the marketplace ... Squeezing generally occurs when one or more parties acquire a substantial supply of a financial instrument or commodity and then use their market power to manipulate market prices in their favor.

Lin, supra note 40, at 1281-82 (citations omitted).

192. Markowski v. SEC, 274 F.3d 525, 527 (D.C. Cir. 2001).

193. See United States v. Mulheren, 938 F.2d 364, 371 (2d Cir. 1991) (finding that market domination "must be viewed in light of the time period involved and other indicia of manipulation"). 
period. ${ }^{194}$ A trader's controlling position in an asset that lasts for minutes or hours may be used to distort the price in that brief window. Indeed, given the linkage between asset closing prices and derivatives, a savvy manipulator would not need to dominate the price for weeks to be profitable; mere minutes would be sufficient. As with long-term market domination, the key is to determine whether the market actor used her controlling position in the market to improperly distort the asset's price.

Both Masri and Amaranth are examples of short-term market control that contributed to or caused an artificial price in the markets. Recall, in Masri, the defendant's transactions constituted 94 percent of all purchases in the asset in the last hour of trading and 75 percent of all purchases for the day. ${ }^{195}$ Masri's domination lasted only a single day, but it was effective; his trades exerted pressure on the asset's price to his benefit, allowing him to profit on his related option contract. ${ }^{196}$ Similarly, in Amaranth, the defendants' market control lasted mere minutes; they sold 99 percent of the asset in the last 4 minutes of the closing window. ${ }^{197}$ Through their brief domination of the market, the defendants were able to distort the asset's price, thereby manipulating the market. Such extreme market domination, as seen in Masri and Amaranth, calls into question whether an asset's price is set by the forces of supply and demand or, rather, by the trader's controlling market position.

Market domination, therefore, is a strong indicator of price artificiality. To the extent that traders use open-market transactions to establish dominance and, subsequently, distort the asset's price, they have harmed the market's pricing efficiency. Market dominance, both in the form of monopolistic ownership and relative transaction

194. See CFTC v. Parnon Energy, Inc., 875 F. Supp. 2d 233, 245 (S.D.N.Y. 2012) (noting that where the defendants acquired 97 percent of the total futures contracts for West Texas Intermediate crude oil supply from January 8, 2008, to January 27, 2008, the CFTC sufficiently pled the "ability to influence prices" element, since the defendant maintained a dominant position in the WTI market); SEC v. Masri, 523 F. Supp. 2d 361, 364 (S.D.N.Y. 2007) (holding that because the defendant placed 7 different orders for TZA shares in the last 10 minutes of the dayamounting to 94 percent of all TZA buy-side activity for the last hour of trading - the SEC raised sufficient facts to plead manipulative intent).

195. Masri, 523 F. Supp. 2 d at 365.

196. Id. at 364-66. Masri may be compared to corrective traders whose "only goal is to discover manipulators and sell shares at the inflated price, thereby trying to minimize the exercise of downward supported price pressure and maximize their profit . . . . Informed traders endeavor to minimize the supported price pressure and maximize their profit." Nelemans, supra note 58, at 1190-91.

197. CFTC v. Amaranth Advisors, L.L.C., 554 F. Supp. 2d 523, 528 (S.D.N.Y. 2008). 
dominance, should result in courts giving those facially legitimate transactions greater scrutiny for their potentially manipulative effect on asset price.

b. Market Volatility. Severe price fluctuations can suggest price artificiality. ${ }^{198}$ Generally, markets experience some level of volatility as conditions change, market expectations are revised, and new information becomes available. ${ }^{199}$ Abnormal price swings, however, may indicate that the asset's price is moving further away from its fundamental value. ${ }^{200}$ Studies have shown that manipulated markets exhibit higher volatility, as nonmanipulative traders try to respond to manipulative trading. ${ }^{201}$ When traders engage in open-market manipulation, they may increase market volatility by exerting unsustainable pressure on the price of an asset. ${ }^{202}$ For example, asset

198. Regression models can be used to show whether price fluctuations are indicative of price artificiality:

Generally, one should be able to examine the prices of the futures contracts at issue through a regression model that has the market fundamental factors as regressors, that is, right-hand-side variables. The residuals from this regression model reflect the effect on prices of factors unrelated to supply and demand fundamentals. If prices are indeed artificial, one will find statistically significant residuals during the alleged manipulation period. In other words, the test for statistically significant residuals from a market fundamental-based regression is the test for price artificiality.

Atanu Saha \& Hans-Jürgen Peterson, Detecting Price Artificiality and Manipulation in Futures Markets: An Application to Amaranth, 18 J. DeRIVATIVES \& HedGE Funds 254, 257 (2012).

199. David C. Donald, Regulating Market Manipulation Through an Understanding of Price Creation, 6 NAT'L TAIWAN U. L. REV. 55, 64 (2011) ("Market manipulation affects the price creation process by influencing the price to reflect not just available information about the issuer, the relevant securities, and the market, but to a material extent the action of the manipulator. As such, manipulation also increases volatility.").

200. Charles R. Korsmo, High-Frequency Trading: A Regulatory Strategy, 48 U. RICH. L. REV. 523, 578 (2014) ("Legacy order-execution algorithms ... often use volume as a proxy for liquidity, and thus may trigger large price movements where it is a poor proxy. Some may be a result of non-manipulative trading strategies whereby HFTs [high-frequency traders] chase shortterm momentum in such a way as to amplify price swings."); X. Frank Zhang, High Frequency Trading, Stock Volatility, and Price Discovery 8 (Dec. 2010), https://papers.ssrn.com/ sol3/papers.cfm?abstract_id=1691679 [https://perma.cc/MR33-J947] ("A large number of unidirectional trades can create price momentum and attract other momentum traders to the stock, a practice that amplifies price swings and thus increases price volatility.").

201. Aggarwal \& Wu, supra note 93, at 1942 ("Overall, these results suggest that prior to the manipulation, manipulated stocks are unexceptional in terms of returns, but they tend to be more volatile. During the manipulation period, manipulated stocks exhibit higher returns, higher liquidity, and higher volatility.").

202. See Nelemans, supra note 58, at 1183, 1192-93 (discussing manipulation in terms of "unsupported price pressures" that increase market volatility and exacerbate informational asymmetries in the market). 
prices that collapse once a trader has exited the market may signal that the price was being artificially supported. ${ }^{203}$

Markowski, again, exemplifies this concept. Once the defendants could no longer support the price of the security in question, the price plummeted by 75 percent in a single day. ${ }^{204}$ The price decrease in Mulheren was much less dramatic but was still an abnormal fluctuation in price for the stock. Prior to the defendant's trading, the security's price changed in small increments of $\$ 0.125 .{ }^{205}$ Yet, after the price increased in response to his transactions, the defendant ceased trading, and the stock fell by $\$ 1.375 .{ }^{206}$ In both instances, the sharp decline in the asset prices was not accompanied by any external news or occurrence that explained the volatility; the most significant change was that the defendant no longer traded the asset. Such price volatility, even when coupled with facially legitimate transactions, should be scrutinized as an indicator of possible open-market manipulation, particularly in the face of the double harm of market instability and the resulting price artificiality.

c. Market Illiquidity. A final factor that may indicate that openmarket trades are being used to manipulate the market is whether the market is small and illiquid, on the one hand, or robust and highly liquid, on the other hand. ${ }^{207}$ A liquid, efficient market is characterized by the ability of traders to execute orders without having the market move against them. ${ }^{208}$ The New York Stock Exchange ("NYSE") and

203. The opposite is also true - that is, a price that rebounds once a trader exits may indicate that the price was artificially depressed. However, it is more likely for manipulators to try to raise prices than depress them. See Aggarwal \& Wu, supra note 93, at 1920.

204. Markowski v. SEC, 274 F.3d 525, 527 (D.C. Cir. 2001).

205. United States v. Mulheren, 938 F.2d 364, 367-68 (2d Cir. 1991).

206. Id. (indicating that between October 16, 1985, and October 17, 1985, G\&W stock moved from $\$ 44.75$ to $\$ 44.875$ and then to $\$ 45$ at different times of the day, but that on October 17,1985 , $\mathrm{G} \& \mathrm{~W}$ common stock closed at $\$ 43.625$ after the defendants sold a large amount of $\mathrm{G} \& \mathrm{~W}$ common stock).

207. See Nelemans, supra note 58, at 1178 ("[L]arge traders in liquid markets and small traders in illiquid markets will sometimes be able to inflate or deflate the price.").

208. Attorney Joseph M. McLaughlin describes market illiquidity as follows:

In an efficient market, stock prices promptly and accurately reflect publicly available information so that an investor who relies on the integrity of the market is also relying indirectly on the information. . . . [A]n efficient market absorbs material misrepresentations into the price of the security so quickly that the ordinary investor cannot make trading profits on the basis of the new information. An inefficient market does not.

Joseph M. MCLAughlin, 1 MCLAughlin on Class ACtions: LAW AND PRACTiCE $§ 5.26$ (14th ed. 2017) (citations omitted); see also Bratton, supra note 23, at 505 (noting that the efficient 
the NASDAQ are prime examples of efficient markets; many securities traded on these exchanges have thousands of traders each minute. ${ }^{209}$ Less-liquid markets include securities traded on the OTC Bulletin Boards and the Pink Sheets, where trades may number in single digits for a single day. ${ }^{210}$ Even in the absence of manipulation, trades are more likely to have an effect on price in smaller markets because there are fewer available counterparties with whom to trade. ${ }^{211}$

Trading strategies - such as placing large orders and marking the close - have a more significant impact on asset price when the market is illiquid. ${ }^{212}$ For a heavily traded security, moving the price would be no small feat. For example, to move stock price of Amazon - which has a market capitalization of over $\$ 900$ billion, average daily trading volume of approximately 3 million shares, and a per-share price of over $\$ 2000^{213}$ - through open-market trades would require, at a minimum, the purchase of 1 percent of the company's outstanding shares. ${ }^{214} \mathrm{On}$

capital market hypothesis makes a "modest prediction that prices will follow a random walk and that no trading strategy based on public information can systematically outperform the market."); James Peck \& Karl Shell, Liquid Markets and Competition, 2 GAMES \& ECON. BEHAV. 362, 363 (1990) ("We say that a market is liquid if the effect of any individual's trades on the prices in that market is small.").

209. See NASDAQ-Most Active Stocks, NASDAQ, https://www.nasdaq.com/markets/mostactive.aspx [https://perma.cc/J329-3PJK]. For example, on September 27, 2018, one of the most heavily traded securities on the NYSE by share volume was General Electric Company, which had over 82 million shares traded. General Electric $(G E)$, YAHOO! FIN., https://finance.yahoo.com/quote/GE/history?p=GE\&.tsrc=fin-srch [https://perma.cc/YCQ3X97Q].

210. See Information for Pink Companies, OTC MKTS., https://www.otcmarkets.com/ corporate-services/information-for-pink-companies [https://perma.cc/9XWX-98V4]. For example, on September 27, 2018 one of the more heavily traded securities on the Pink Sheets by share volume was Acology, Inc., which had approximately 2 million shares traded. Acology, Inc. (ACOL), YAHOO! FIN., https://finance.yahoo.com/quote/ACOL/history?p=ACOL\&.tsrc=finsrch [https://perma.cc/YA7F-YKN7] .

211. Charles R. Korsmo, Mismatch: The Misuse of Market Efficiency in Market Manipulation Class Actions, 52 WM. \& MARY L. REV. 1111, 1147 (2011) [hereinafter Korsmo, Mismatch] (noting that in efficient markets, there are sufficient numbers of arbitrageurs that will take the other side of a trade, thereby making it nearly impossible for a manipulator to create an artificial price).

212. Id. at 1145 ("Simply by placing a market purchase order, a would-be manipulator can often increase the observed market price by the amount of the spread, which can be significant in thinly traded stocks.").

213. These numbers were as of August 5, 2018. Amazon.com, Inc. (AMZN), YAHOO! FIN., https://finance.yahoo.com/quote/AMZN/ [https://perma.cc/4YBS-7V3X].

214. This 1 percent formulation has been adopted in the literature:

As Fischel and Ross point out, "[t]o the extent that the evidence supports the existence of a price pressure effect, it indicates that securities have supply and demand elasticities no smaller in magnitude than 1." This means that a manipulator would need to buy at 
the other hand, a trader may be more effective in moving the price of Euroseas Ltd., which has a market capitalization of approximately $\$ 14$ million, an average daily trading volume of a little over 3000, and a per share price under $\$ 2 .{ }^{215}$ Open-market manipulation schemes are likely to be more successful in, and harmful to, illiquid assets because of the limited volume of trading. Indeed, the manipulation schemes in Markowski and Masri, discussed above, all occurred in smaller, illiquid markets.

Another feature of less-liquid markets is that there is less information available about the issuers and the value of the assets because of lower disclosure requirements. ${ }^{216}$ The dearth of information means that any information is likely to exert pressure on asset price. ${ }^{217}$ High-volume or higher-than-usual volume trades in small, illiquid markets communicate information to other traders that either the highvolume trader has information about the asset or that she is attempting to manipulate the price. Studies have shown that open-market manipulation is more likely to be successful when other traders do not know what motivates large orders. ${ }^{218}$ This level of information asymmetry is characteristic of thinly capitalized markets, and the asymmetry amplifies the impact of open-market manipulation and increases the likelihood of price distortion. Thus, transactions utilizing open-market manipulation strategies in highly illiquid markets warrant

least 1 percent of a company's outstanding shares-a purchase that would be in the billions of dollars for Microsoft - in order to raise the share price by a measly 1 percent.

Korsmo, Mismatch, supra note 211, at 1147 (citation omitted).

215. These numbers were as of August 5, 2018. Euroseas Ltd. (ESEA), YAHOO! FIN., https://finance.yahoo.com/quote/esea?p=esea\&.tsrc=fin-srch [https://perma.cc/KKJ2-B2MH]. There is no indication that the price of Euroseas has been or is now being manipulated. The company was chosen for illustrative purposes only.

216. SEC, REPORT ON THE MUNiCIPAL SECURITIES MARKet 2, 142 (July 31, 2012), https://www.sec.gov/news/studies/2012/munireport073112.pdf [https://perma.cc/Q6DQ-Y3NN] ("Despite its size and importance, the municipal securities market has not been subject to the same level of regulation as other sectors of the U.S. capital markets ... [T] he municipal securities market is relatively illiquid and opaque, with substantially less transparency than the equities markets, particularly on a pre-trade basis.").

217. See MARKus K. BRUNNERMEIER, ASSET PRICING UNDER AsYMMETRIC INFORMATION: BUBBLES, CRASHES, TECHNICAL ANALYSIS, AND HERDING 1 (2001) ("Financial markets are driven by news and information ... . This information affects traders' expectations about the uncertain value of an asset."); Thompson \& Sale, supra note 50, at 873 ("[M]andated disclosures are detailed and are therefore potential sources of manipulation and fraud.").

218. Franklin Allen \& Douglas Gale, Stock-Price Manipulation, 5 REV. FIN. STUD. 503, 509 (1992) ("[A] manipulator who is uninformed can make a profit simply by buying and selling the stock.”). 
greater scrutiny to determine whether the trader should be held liable for open-market manipulation.

2. Market Integrity. Most insidiously, open-market manipulation undermines market integrity because traders use the markets' structure and interconnectedness to effectuate their manipulative schemes. Trading in the financial markets is a zero-sum game-each trader's gain comes at the cost of another's loss. ${ }^{219}$ Market actors, nonetheless, expect that their losses are not because their counterparties had an unfair advantage. Traders and the public expect that gains are fairly earned from a person's skill, research, ${ }^{220}$ or even luck. Public perception that the markets are fair is essential to their proper functioning. When facially legitimate trades are used to allow a trader to profit unfairly, this undermines the markets' integrity, creating the impression that the markets are rigged. Open-market manipulation erodes public trust and confidence in the markets by facilitating unfairness in the markets under the guise of legitimate transactions.

But what does it mean to say that the markets ought to be fair? Or that transactions are unfair? As a regulatory concept, fairness is hazy; inserting it into the law of market manipulation may cause more confusion than clarity. ${ }^{221}$ Courts, regulators, and scholars invoke

219. See JACK L. TREYNOR, Types and Motivations of Market Participants, in AsSOCIATION FOR INVESTMENT MANAGEMENT \& RESEARCH, EXECUtion TECHNiQues, True Trading COSTS, AND THE Microstructure OF MARKets 35, 35 (Katrina F. Sherrerd ed., 1993) ("[T]rading is a zero-sum game ... . Every trade will have one winner and one loser...."); William J. Baumol, Speculation, Profitability, and Stability, 39 REV. ECON. \& STAT. 263-64 (1957) ("Whatever one group of traders gains another must lose ... ."); John C. Coffee, Jr., Market Failure and the Economic Case for a Mandatory Disclosure System, 70 VA. L. REV. 717, 733 (1984) (explaining that secondary-market trading does not create wealth because one party's gain comes from another's loss); Lawrence H. Summers \& Victoria P. Summers, When Financial Markets Work Too Well: A Cautions Case for a Securities Transactions Tax, 3 J. FIN. SERVS. RES. 261, 272 (1989) (recognizing that trading is a zero-sum game); Whitehead, supra note 25, at 57-58 (discussing the zero-sum game that emerges when firms choose to transfer risks related to capital raising to a transferee's shareholders).

220. Yet still, "an informed trader generally ignores the loss to uninformed traders from [the informed trader's] decision to engage in information research." Ian Ayres \& Stephen Choi, Internalizing Outsider Trading, $101 \mathrm{MICH}$. L. REV. 313, 335 (2002). Further, "[t]he informed trader compares a private benefit (the transfer of trading profits) to the private (and social) cost of research, but ignores a host of external social costs and benefits that are likely to determine whether the informed trading is on balance socially productive." Id.

221. Robert W. McGee, Applying Ethics to Insider Trading, 77 J. Bus. ETHICs 205, 210 (2008) ("Trade cannot be free, it must be fair, whatever that means." (citation omitted)); Sale \& Langevoort, supra note 21, at 777 ("Most would agree that an omission of [some] risk renders the advice [provided by lawyers in corporate disclosures] misleading and unfair to the client."). 
fairness as a basis for prohibiting certain behavior that as a society we deem unacceptable. For example, the grounds for punishing insider trading, another form of market abuse, are often phrased in terms of fairness-allowing insiders to trade on the basis of material nonpublic information is unfair to the corporation to which the insiders owed a duty. ${ }^{222}$ For unfairness to be a meaningful basis for evaluating harm to the markets, the notion of fairness must be unpacked as it relates to the financial markets.

Reliance on fairness implicates two principles that are necessary for defining its scope as a basis of liability. On the one hand, not all unfairness in the market can or should be grounds for liability. ${ }^{223}$ That would make the concept of fairness overbroad, and it would contradict the fundamental nature of the markets. On the other hand, trading with full knowledge that one's profits are certain cuts against the honesty and integrity of the markets. ${ }^{24}$ Open-market manipulation, particularly covered manipulation, brings both of these considerations to the fore. Even in the absence of misconduct or manipulation, traders do not have access to the same information. ${ }^{225}$ Yet, some transactions may be unfair, such as when traders create market conditions that guarantee their profits or unjustly make it more difficult for other

222. Early scholarship on insider trading viewed equality of information among public investors as an underlying justification of insider-trading laws. See, e.g., EDWARD S. HERMAN, Corporate Control, Corporate Power 116 (1981); Charles C. Cox \& Kevin S. Fogarty, Bases of Insider Trading Law, 49 OHIO ST. L.J. 353, 359-60 (1988); David Ferber, The Case Against Insider Trading: A Response to Professor Manne, 23 VAND. L. REV. 621 (1970); William H. Painter, Rule 10b-5: The Recodification Thicket, 45 ST. JOHN's L. REV. 699, 713-14 (1971). Similarly, lower courts also initially endorsed this view, believing that insider trading was unfair to public investors, in general, because the latter did not have access to the same information prior to trading. See, e.g., SEC v. Tex. Gulf Sulphur Co., 401 F.2d 833, 848 (2d Cir. 1968) ("[Rule 10b$5]$ is based in policy on the justifiable expectation of the securities marketplace that all investors trading on impersonal exchanges have relatively equal access to information ... ."); Speed v. Transamerica Corp., 99 F. Supp. 808, 829 (D. Del. 1951), aff'd with modifications as to damages, 235 F.2d 369 (3d Cir. 1956). The Supreme Court rejected this broad reading of Rule 10b-5 and instead deemed trading on the basis of nonpublic information to be illegal and "unfair" only to the extent that the trader owed a duty to the corporation whose shares were traded. It is the violation of the duty the trader owed the corporation that makes insider trading unfair to the corporation, rather than to the public markets as a whole. Chiarella v. United States, 445 U.S. 222, 231-35 (1980).

223. Chiarella, 445 U.S. at 232 ("[N]ot every instance of financial unfairness constitutes fraudulent activity under $\S 10(\mathrm{~b})$.") (citation omitted).

224. United States v. Chiarella, 588 F.2d 1358, 1362 (2d Cir. 1978) ("[B]etting on a 'sure thing' is anathema to the ideal of 'fair and honest markets'...." (citation omitted)), rev'd on other grounds, 445 U.S. 222.

225. BRUNNERMEIER, supra note 217 , at 1 ("[I]n reality different traders hold different information."). 
traders to profit. Determining the point at which a transaction is not "fair," then, is important for identifying when open-market transactions harm the market.

There are three possible formulations of fairness. First, fairness may refer to traders having equal access to information. Under this definition, it would be unfair to trade with someone who does not have the same information. Such a definition of fairness is inappropriately broad and limits all profitability within the markets. ${ }^{226}$ Analysts, for example, contribute to market efficiency by researching assets and making educated recommendations on whether to buy, sell, or hold. The process by which this information is absorbed into the markets facilitates asset pricing. However, if a trader had to inform her counterparty of the results of her research before trading, there would be no profits to be earned, nor, more importantly, would there be any incentives to do research. ${ }^{227}$ Open-market trades, therefore, cannot be harmful simply because a trader appropriately has more information than her counterparty.

A second definition of fairness considers the trader's ability to execute transactions at the "correct" price. Thus, if open-market trades improperly affect the asset price, the trades are unfair. Defining unfairness in relation to the price of the asset conflates price artificiality with harm to market integrity, which ought to be treated as separate bases for liability. Price distortion harms market integrity, but a definition of fairness should identify how a transaction's unfairness can be an independent basis of liability. Consequently, this definition is an unsatisfactory way to frame how open-market transactions harm market integrity.

Third, fairness may refer to the absence of unjust wealth transfers. Although trading in financial assets is a zero-sum game, the transfer of wealth between parties is expected to be because of the skill or luck of the counterparty. ${ }^{228}$ Arguably, fair markets should provide a parity of

226. See Kevin S. Haeberle \& M. Todd Henderson, Information-Dissemination Law: The Regulation of How Market-Moving Information is Revealed, 101 CORNELL L. REV. 1373, 1429 (2016) (discussing the view that "fairness-inspired" reforms that aim to make information available to the public would simultaneously leave investors worse off).

227. See McGee, supra note 221, at 211 ("What is unfair is to force [individuals] to disclose such information to people who have done nothing to earn it."); Daniel J. Solove, The Virtues of Knowing Less: Justifying Privacy Protections Against Disclosure, 53 DUKE L.J. 967, 991 (2003) (explaining that privacy permits individuals to engage in meaningful activities that have positive value; that it encourages development; and that without this protection, individuals might not engage in such activity).

228. See McGee, supra note 221, at 211 (arguing that some people develop more skills or are 
opportunity between counterparties in the possibility that one may lose and the other gain. A transaction is unfair and harms the markets' integrity if it allows one trader to place her thumb on the scale such that the playing field is no longer level. This view of fairness rests on the reasonable expectations of the parties that their transactions have the same likelihood of success or failure. A trader that creates market conditions that make her counterparties' success less likely reduces the public's confidence in the fairness of the markets. This Article adopts this third definition of fairness because it best captures how openmarket transactions can be unfair and detrimental to market integrity, while limiting the scope of conduct that gives rise to liability for covered manipulation schemes.

In connecting fairness with the parties' reasonable expectations, the scope of liability for harm to market integrity is confined to openmarket transactions in which traders have a contractual relationship. In naked manipulation schemes, trades are between anonymous counterparties on public exchanges. The absence of a contractual relationship between the parties means that they have no expectations of each other. And, there is no expectation that traders disclose their trading strategies to their counterparties. Thus, claims for open-market manipulation based on naked transactions should be limited to claims based on harm to market efficiency. ${ }^{229}$ With covered manipulation, on the other hand, the trader has a financial contract or instrument that is directly affected by her open-market trades. While counterparties to those trades cannot claim unfairness, the counterparties to the contract may allege manipulation if the open-market trades were used to undermine the reasonable expectations of the parties' related contractual agreement.

In covered manipulation schemes, the manipulator tilts what ought to be a neutral contract or financial instrument into an arrangement that benefits her by interfering with the objective valuation methods on which the parties agreed. Specifically, in derivatives and similar financial instruments, the payout is determined with reference to a benchmark or other objective market measure, such as the closing price of the asset on a specified day ${ }^{230}$ Parties to these

naturally better at something than their competitors, and that those more-equipped people should not be penalized by regulation that levels the playing field).

229. See infra text accompanying note 253 (explaining reasons for limiting the scope of liability for market integrity).

230. A benchmark is a price, rate, or index that measures one or more underlying assets, prices, or other data based on a formula, value assessment, or market survey. Fletcher, 
contracts rely on objective valuation methods to ensure that no party has control or influence over the means of valuation. ${ }^{231}$ When a trader interferes with the contractual basis of valuation, she diminishes the parity of opportunity that these instruments ought to provide for each party to the contract. Although a counterparty expects others in the markets to act in a self-interested manner, efforts to skew the means of valuation undercut counterparties' reasonable expectations. ${ }^{232}$

Recall, Amaranth and its counterparties entered into a swap, agreeing on an objective valuation method-the closing price of the NYMEX. ${ }^{233}$ However, upon realizing that the closing price would result in significant losses, the defendants executed transactions to distort the closing price of the NYMEX, thereby negating the objectivity of the agreed-on valuation measure. ${ }^{234}$ By attempting to influence the swaps' payout, the defendants skewed the transaction to their benefit, contradicting the parties' reasonable expectations. The defendants' gains on the swap agreements, therefore, were unfair because they were an unjust transfer of wealth from the swap counterparties to Amaranth. Given the unfairness of Amaranth's conduct toward its counterparties and the harm its trades inflicted on market integrity, the Amaranth defendants should be liable for openmarket manipulation. Similar assertions regarding unfairness and the reasonable expectations of counterparties can be made with respect to Masri.

Maintaining market integrity is foundational to the markets' efficient functioning. Yet, because of the amorphousness of the concept of fairness in the markets, lawmakers have shied away from using fairness as an independent basis of liability. Undeniably, openmarket manipulation implicates notions of fairness, even in instances when pricing efficiency was not harmed, and in instances when that harm cannot be proven. Current market structure-in which commodities, securities, and derivatives are inextricably linkedfacilitates complex risk strategies, but this structure also makes openmarket manipulation a profitable undertaking. When traders exploit

Benchmark Regulation, supra note 97, at 1930-31.

231. Id. at 1944.

232. Patricia A. McCoy, Systemic Risk Oversight and the Shifting Balance of State and Federal Authority over Insurance, 5 U.C. IRVINE L. REV. 1389, 1414 (2015) (noting that under the DoddFrank Act, "[s]tandardized derivatives must now be cleared and executed through central clearinghouses to improve transparency and limit counterparty risk" (citation omitted)).

233. Supra notes $157-58$ and accompanying text.

234. Id. 
market structure and bias market outcomes in their favor, they harm the market by robbing other market participants of an equal opportunity to participate in a fair market. ${ }^{235}$ Even if such conduct does not result in an artificial price, it does result in unjust wealth transfers, which indicates that the transactions impaired market integrity and were, therefore, manipulative.

\section{A Role for Market Discipline?}

Before any discussion of what regulatory intervention to identify and punish open-market manipulation ought to look like, it is necessary to consider whether the market can discipline the perpetrators, given that their trades are executed on the open market. Although regulations are important to correct market failures like market manipulation, ${ }^{236}$ enforcement actions and private suits may not be needed if the markets punish actors for their misconduct. Regulatory restraint, in such cases, is more appropriate. ${ }^{237}$

In a seminal article on market manipulation, Professors Daniel R. Fischel and David J. Ross posit that attempts to manipulate through the open market are doomed to fail because the markets will correct attempts to distort the price through trades. ${ }^{238}$ Fischel and Ross argue that even if trades move an asset's price upwards, the price will revert to its normal value once the asset is sold on the open market. ${ }^{239}$ Naked manipulation, they assert, is self-deterring because it cannot be profitable, and scarce regulatory resources should, therefore, not be directed toward it. ${ }^{240}$ In sum, their argument goes, regulation of open-

235. Jill E. Fisch, Jonah B. Gelbach \& Jonathan Klick, The Logic and Limits of Event Studies in Securities Fraud Litigation, 96 TEX. L. REV. 553, 560 (2018) (explaining that misrepresentations affect stock prices and result in harm to the market).

236. Rebecca Söderström, Regulating Market Manipulation: An Approach to Designing Regulatory Principles 23 (Uppsala Faculty of Law, Working Paper No. 1, 2011) https://www.jur.uu.se/digitalAssets/585/c_585476-1_3-k_wps_2011_1.pdf [https://perma.cc/DJ9BDXSR] ("The main justification to regulate the activity on the financial markets is to help the financial markets perform more efficiently.").

237. See, e.g., Stephen J. Choi, Law, Finance, and Path Dependence: Developing Strong Securities Markets, 80 TEX. L. REV. 1657, 1692 n.254 (2002) (explaining how foreign legislation "retarded the development of the markets" when enacted in response to price-manipulation scandals involving the German commodities markets).

238. See Fischel \& Ross, supra note 18, at 518 ("[A] manipulator who is able to convince market participants that he is informed at the time of purchase must do the opposite at the time of sale. If he cannot, he would realize losses even if he were able to sell at the market price.").

239. See id. at 521 (noting that a trader must hope that "prices will fall after he sells and will not rise again simultaneously with his subsequent purchases").

240. Id. at 518-19. 
market manipulation ought to be left to the markets, because market forces will correct any price distortion, and because the conduct is unprofitable, thereby making it self-deterring. ${ }^{241}$ However, neither claim is persuasive nor correct with respect to open-market manipulation, whether naked or covered. Thus, legal intervention is needed.

Certainly, in some of the case studies discussed above, market forces were able to correct for trader misconduct. In Markowski and Amaranth, the traders' schemes ultimately led to the demise of their respective firms; in Mulheren, the consequences were not as grave, but the trader still lost thousands of dollars because of the trade. ${ }^{242}$ In these cases, it could be argued that market discipline worked well because the traders paid a high cost for manipulating the markets. Examples of such spectacular failures ought to serve as a deterrent for would-be manipulators, thereby minimizing the occurrence of such schemes. Yet, even if open-market manipulation schemes result in significant losses for the trader, that does not mean that there is no role for regulatory intervention. Determining whether a particular manipulation scheme should be subject to enforcement actions requires more than an inquiry into whether the trader profited from her scheme. ${ }^{243}$

Even ultimately unprofitable schemes impair market efficiency and integrity. The inability of the trader to profitably sustain her openmarket scheme does not minimize the impact that her conduct has on the market. For example, the transactions in Markowski were selfdestructive and unprofitable; however, they still upended the market for the securities at issue, resulting in pricing inefficiencies that persisted for several months. ${ }^{244}$ Further, market actors other than the defendants likely also lost when the price for the asset plummeted. Because the scope of open-market manipulation schemes spreads beyond the losing trader, there is still a need for regulatory enforcement, even when the trader incurs losses. Indeed, declining to bring enforcement suits against unprofitable manipulation schemes may do more harm than good to the markets. Such an enforcement strategy would signal that incurring some losses may be a way for manipulative traders to evade prosecution, thereby weakening the

241. $I d$.

242. Supra Part II.B.

243. Markowski v. SEC, 274 F.3d 525, 529-30 (D.C. Cir. 2001).

244. Id. at 530 . 
anti-manipulation regulatory framework.

Additionally, market discipline is likely not effective in curbing open-market manipulation when the scheme occurs in separate markets. Recall, covered-manipulation schemes profit from movement in one market that triggers a right in another market. As such, when open-market trades are used to exert price pressure, thereby triggering payments owed on a related contract, the scheme is nonetheless profitable even after the manipulative effects of the trades have dissipated and the asset-price returns to its nonmanipulated level. The trader, therefore, is able to profit from the increase in price through her contract, but is not exposed to the asset-price decrease, when and if it occurs. The disconnect between the market that is being manipulated and the market that is the source of the trader's profits means that market discipline is muted in these scenarios. Enforcement is needed to punish and deter open-market manipulation given the impotence of market forces.

Further, open-market manipulation can be profitable. It is not self-deterring, and, therefore, regulatory intervention is necessary. Covered manipulation has significant profit potential because of the use of derivatives in these schemes. As discussed above, derivatives allow traders to benefit from or protect themselves against the changing price of an asset without owning the asset. These instruments can be highly leveraged, which provides traders the opportunity to gain high exposure to the asset's price movement for a small cost. ${ }^{245}$ For example, suppose a trader purchases an option that is tied to the price of a barrel of oil, as determined by the leading oil benchmark. The trader is entitled to payment if the benchmark settlement price of oil is above $\$ 100$ per barrel. For exposure to the price of 1000 barrels of oil, the trader must pay five percent of the value of the contract $(\$ 5000)$. If the trader is able to exert pressure on the benchmark settlement price, causing it to settle at or above $\$ 100$ per barrel, the trader earns a profit of $\$ 95,000 .{ }^{246}$ Her profits are possible without owning a barrel of oil and, importantly, without the need to sell oil to the market, which would decrease her profits. The possible profits from similar openmarket schemes make them attractive for would-be manipulators.

245. Dick Bryan \& Michael Rafferty, Financial Derivatives and the Theory of Money, 36 ECON. \& SOC. 134, 136 (2007) (“[D]erivatives provide 'leverage' and reduce the costs of hedging against unwanted price movements. As a corollary, they also cheapen the cost of speculating on price movements.").

246. This is the price of 1000 barrels at $\$ 100$ minus the cost of the contract-that is, $\$ 100,000$ $-\$ 5000=\$ 95,000$. 
Enforcement is important, therefore, to curb the occurrence of similar conduct in the markets.

Despite the ability of market forces to sometimes respond to open-market manipulation, lawmakers play a vital role in ensuring the efficiency and integrity of the markets. Even when the markets are able to respond, regulators should still intervene to hold traders accountable for unprofitable attempts to manipulate the markets. Furthermore, because market discipline is unable to reach some forms of open-market manipulation, there remains a role for regulators to minimize the impact of open-market manipulation on the markets' functioning.

\section{Proposals for Reform}

Open-market manipulation likely will remain part of the financialmarket landscape, given its profitability and the inherent difficulty of detection. The Commissions' recognition of open-market manipulation and willingness to prosecute it are important and necessary first steps. However, because of the flawed approach they have adopted, the Commissions are ineffective at addressing openmarket manipulation. As with all forms of market manipulation, there is no proverbial silver bullet for eliminating open-market manipulation, but it is possible to minimize its occurrence and impact on the markets. This Article's proposals are aimed at assisting the Commissions, courts, and private parties in effectively detecting and improving enforcement outcomes against open-market manipulation, without deterring or punishing beneficial legitimate transactions.

1. Adopt a Harm-Based Approach. The first, and most obvious, recommendation is that the Commissions - and any relevant courts jettison the intent-centric approach and replace it with the framework this Article proposes. The incomplete nature of the Commissions' framework curtails their ability to effectively police open-market manipulation. Embracing the harm-based approach of this Article would provide a coherent and cogent basis on which to ground liability for open-market manipulation. The current intent-centric theory is only half finished. It divorces open-market manipulation from the concept of market harm, transforming it into something akin to a thought crime, with no evidence of illegal conduct. The Commissions, and private parties adopting this approach, actually weaken their claims of market manipulation. Courts are reticent to ground liability on bad intentions in the absence of misconduct or injurious impact. The 
harm-based proposal enables plaintiffs to demonstrate that their manipulation allegations target harmful conduct that masquerades as legitimate transactions - not actually legitimate transactions.

Importantly, the proposed harm-based approach makes explicit what the courts are already doing implicitly in their analysis of openmarket manipulation. Plaintiffs frame their allegations in terms of the intent of the trader to manipulate; in response, the courts use the language of intent to assess their claims. Yet, a closer reading of the cases demonstrates that the court is often in search of indicia of harm, either in the form of inefficiency or unfairness. Evidence of manipulative intent is often used to decipher whether and how transactions harmed the markets. In addition to being intellectually dishonest and raising due process concerns,${ }^{247}$ this approach ultimately impedes effective regulation of open-market manipulation. If plaintiffs are not required to carry their burden to establish that traders' conduct was harmful, then there cannot be a complete inquiry into whether the conduct was manipulative; and defendants do not have the opportunity to adequately defend against this implied basis for liability. Conflating intent and harm stymies the development of legal precedent on the question of open-market manipulation. Explicit adoption of intent and harm as twin bases for liability would reduce much of the judicial confusion surrounding open-market manipulation.

2. Amend the Price-Artificiality Standard. Price artificiality is an established basis for market manipulation but is rarely raised in claims of open-market manipulation, despite the fact that price distortion is a noteworthy negative effect of open-market manipulation. This is because the elements to prove price artificiality are exacting to the point of being unattainable. Interestingly, the CFTC imposed this standard on itself in one of its earliest market manipulation cases, ${ }^{248}$ courts have since adopted the test, which has become an albatross around the Commissions' necks. ${ }^{249}$ Because the test includes both a specific intent requirement and a showing of market power, it is a difficult one to fulfill. By requiring that defendants have the ability to influence prices, the test focuses on the defendants that dominate or control the market and use their market position to influence prices, as

247. Specifically, a defendant cannot adequately circumscribe her conduct ex ante if she is unaware of the standards by which she will be judged ex post. This creates concerns regarding enforcement of laws for which parties have no prior notice.

248. In re Cox, No. 75-16, 1987 WL 106879, at *4 (C.F.T.C. July 15, 1987).

249. See Part I.C.3 for the price artificiality test. 
is done in corners and squeezes. ${ }^{250}$ This narrows the scope of the priceartificiality test by excluding price distortion that is unconnected to market power, though even that distortion is possible in open-market manipulation.

The standard for price artificiality should be changed to require general, rather than specific, intent. Additionally, if a claim of price manipulation does not involve allegations of market-power abuse, the plaintiff should not be required to demonstrate that the defendant dominated the market. Making these changes to the test would expand the applicability of price manipulation as a basis for liability, particularly for open-manipulation schemes that do not exclusively rely on market domination to create an artificial price. Furthermore, changing to general intent harmonizes the price-manipulation standard with other anti-manipulation provisions.

Price distortion is one of the primary ways in which open-market manipulation harms the market, but the current standard does not provide an avenue by which these allegations can be made. Continuing to apply the current test would render price manipulation via openmarket manipulation an unprosecutable crime. ${ }^{251}$ This statement is not hyperbolic-when the price-artificiality standard was the only basis available to the CFTC for prosecuting market manipulation, the Commission won only a single case in over thirty years. ${ }^{252}$ Open-market manipulation cannot be addressed meaningfully if the Commissions are stymied by an onerous standard. Redefining the price-artificiality standard, therefore, is essential to holding accountable those who engage in open-market manipulation.

3. Recognize Liability for Harming Market Integrity. Maintaining market integrity is a well-accepted principle of financial regulation, yet it is not recognized as an independent basis for liability. For example, although liability for insider trading is discussed in terms of fairness, such liability is actually based on principles of fraud. As such, while market integrity must be maintained, liability for breaching it is based on other grounds. Open-market manipulation undoubtedly undermines market integrity by creating unfair market conditions that allow manipulators to profit at the expense of other market

250. For the difference between cornering and squeezing, see text accompanying supra note 191.

251. Markham, Manipulation, supra note 93, at 283.

252. Abrantes-Metz, Rauterberg \& Verstein, supra note 182, at 359. 
participants. Developing a new basis for liability requires more details than are possible in this Article, but the scope of the concept, specifically as a private cause of action, is explored briefly herein. ${ }^{253}$

A cause of action based on market integrity would focus on the fairness of the manipulator's conduct vis-à-vis her counterparty. This theory of liability would rest on holding the manipulator liable for breaching the reasonable expectations of the counterparty at the time of contracting. In this regard, liability for a breach of market integrity would be framed as akin to a breach of the implied covenant of good faith and fair dealing in a contract. The covenant of good faith and fair dealing is a part of every contract, and it protects the parties' reasonable, even if unstated, expectations upon entering into the contract. ${ }^{254}$ Interestingly, framing liability for market integrity as a contract-like cause of action would raise the possibility that parties might contractually waive the right to sue for open-market manipulation, even if one attempts or is successful in price distortion. ${ }^{255}$ In such instances, harm to market integrity would not be a viable basis for liability; however, if prices have been distorted, the Commissions

253. Whether and to what extent third parties whose transactions are affected by open-market manipulation may bring a cause of action based on market integrity is beyond the scope of the current discussion. This Article frames market integrity liability as unfairness which is caused by a violation of a party's reasonable expectations to a contract. $C f$. supra Part III.B.2 (defining market integrity in terms of counterparties' reasonable expectations in covered transactions). In so framing market integrity, this Article relies on privity of contract to uphold the proposed market-integrity cause of action. But this Article recognizes that market integrity may be framed more broadly to encompass third parties who are not in privity of contract with the manipulator. Should one frame market integrity more broadly, it would be akin to the fraud-on-the-market theory in which reliance of third parties may be presumed if misinformation is injected into an efficient market. See Korsmo, Mismatch, supra note 211, at 1124-28 (discussing the theoretical justifications underlying the fraud-on-the-market theory). If unfairness is framed as such, this would make the market-integrity cause of action available both to third parties who were in the market at the time of the manipulative acts and to regulators seeking to punish the conduct. However, in the interest of space and time, this Article consciously avoids this discussion and instead focuses on framing the proposed cause of action narrowly.

254. Steven J. Burton, Breach of Contract and the Common Law Duty to Perform in Good Faith, 94 HARV. L. REV. 369, 371 (1980) (explaining that "[t]he good faith performance doctrine establishes a standard for contract interpretation and a covenant that is implied in every contract" and that "the courts employ the good faith performance doctrine to effectuate the intentions of parties, or to protect their reasonable expectations").

255. Again, to draw parallels to insider trading laws, this is similar to the Supreme Court's assertion in United States v. O'Hagan that disclosure to one's principal(s) of one's intention to use material nonpublic information for personal gain would invalidate claims of insider trading under the misappropriation theory. See United States v. O'Hagan, 521 U.S. 642, 651-52 (1997) (comparing the traditional or classical theory and the misappropriation theory of insider trading liability). 
may nonetheless bring suit on the basis of harm to market efficiency. Recognizing harm to market integrity as a private cause of action, therefore, would not limit the ability of regulators to prosecute openmarket manipulation; rather, it would supplement the options available to the parties that are most affected by unfair and exploitative trades.

4. Implement Disclosure Obligations for Certain Trading Strategies. Open-market manipulation relies heavily on specific trading strategies that can impact and possibly distort prices. ${ }^{256}$ An extreme-but highly effective-response to the problems these strategies pose would be banning them entirely. Per se rules avoid confusion and allow for ease of enforcement. ${ }^{257} \mathrm{~A}$ ban on naked short selling and banging the close, for example, would draw a bright line and transform these types of trades into impermissible conduct, without regard for the intent of the trader. A blanket proscription on certain trades would lower the costs of detecting open-market manipulation, and enforcement would likewise be simplified. It is doubtful, however, that such a course of action for open-market manipulation schemes would be in the best interest of the markets and traders. The trading strategies used in open-market manipulation can sometimes enhance market efficiency, increase liquidity, and improve risk allocation in the markets. ${ }^{258}$ Further, traders may use a myriad of strategies, yet to be identified, to undermine market efficiency and integrity. Banning trading activities that are currently known makes way for traders to develop other strategies that may have the same effect but are excluded from the bright-line prohibition. A complete ban on these activities, therefore, would be a blunt response to a nuanced problem.

A more promising response would be to impose disclosure requirements on traders who employ trading practices that may be used in open-market manipulation schemes. ${ }^{259}$ To be effective, the disclosure obligation should be twofold: internal, ex ante disclosures

256. Fisch, Gelbach \& Klick, supra note 235, at 560-61 ("[T]he Supreme Court subsequently noted in Halliburton II, '[i]n the absence of price impact, Basic's fraud-on-the-market theory and presumption of reliance collapse." (citation omitted)). Hence, in the absence of price impact, it may be difficult to categorize trader behavior as manipulative.

257. Thel, supra note 36, at 289 ("Objective rules can interdict undesirable trades without a costly and perhaps hopeless inquiry into the trader's motives.”).

258. See supra note 106 and accompanying text.

259. Kevin E. Davis \& Anna Gelpern, Peer-to-Peer Financing for Development: Regulating the Intermediaries, 42 N.Y.U. J. INT'L L. \& POL. 1209, 1248 (2010) (“[T]he bulk of regulatory emphasis in securities issuance and trading is on disclosure."). 
and external, ex post disclosures. First, entities should develop internal guidelines that clearly state whether and under what conditions their traders are allowed to engage in the trading strategies in question. ${ }^{260}$ The internal guidelines should specify who may authorize use of these trading strategies, what factors should be considered in the decision to approve the request, the duration of the authorization, and under what circumstances trades can be exempt, among other details. Such ex ante rules would delineate the boundaries of acceptable conduct and minimize the abusive use of certain trading strategies. Trading in violation of the trader's own internal guideline would raise red flags to lawmakers and may serve as the basis for further inquiry into the harm of the transactions on the markets. Consequently, preventing openmarket manipulation becomes part of an entity's compliance obligations and serves as a first line of defense against improper and damaging conduct in the markets.

Second, after executing certain types of trades, traders should selfreport their activity to the Commissions. In these disclosures, traders should reference compliance with internal guidelines. They should also provide justifications for their trading strategies. These disclosures would assist regulators in detecting possible open-market manipulation and in targeting their resources to investigating whether the transactions were harmful to the markets. Implementing ex ante, internal guidelines and ex post trade disclosures would benefit regulators, traders, and market participants. Through these steps, trading transparency would be increased, improving detection of potentially harmful transactions. The disclosure requirements would likely deter traders from employing problematic trading strategies without bona fide reasons, since using such strategies would expose them to additional scrutiny from both regulators and their counterparties.

\section{BENEFITS AND DRAWBACKS}

This Article's proposed approach to open-market manipulation has several benefits for the markets and lawmakers if embraced by the Commissions and the courts. This Part begins with a brief discussion of these benefits. It goes on to identify drawbacks that may arise from the

260. See, e.g., Veronica Root, The Compliance Process, 94 IND. L.J. (forthcoming 2018) (manuscript at 18-19), https://ssrn.com/abstract=3151893 [https://perma.cc/32EG-SPAQ] (discussing the uses of internal guidelines as a way to prevent illegal conduct within firms). 
proposed harm-based approach. This Part concludes by addressing some unresolved questions that this Article raises.

\section{A. Potential Benefits}

This Section discusses three ways that this Article's harm-based approach and related proposals could improve the markets' approach to open-market manipulation. First, this Article's approach would reduce the costs of trades. Second, it would increase market certainty of the contours of liability for open-market manipulation, while providing regulators with flexibility in enforcement. Third, it would involve private parties in their own regulation, thereby increasing the likelihood of success.

1. Reduced Transaction Costs. An ineffective enforcement strategy against market manipulation has many of the same consequences as an absence of anti-manipulation laws. Markets in which manipulation goes unaddressed have higher transaction costs because market actors must account for possible manipulation in their pricing. ${ }^{261}$ Market participants who fear that their counterparties may exploit the markets to unfairly profit may refuse to enter into these transactions or only do so at a higher cost. Increased transaction costs result in fewer transactions being executed and a reduction in market liquidity overall. ${ }^{262}$ Similarly, the breadth of the Commissions' intentcentric approach may have discouraged some from engaging in beneficial transactions for fear of liability, thereby further reducing market liquidity and increasing transaction costs.

This Article's approach would be more effective in identifying open-market manipulation and separating it from legitimate transactions, using as a basis the harm the transactions inflict on the markets or counterparties. With the harm-based approach, the markets would be assured that the government is more effective in its efforts to detect, minimize the occurrence of, and punish the perpetrators of open-market manipulation. A more robust and theoretically sound approach would ensure that only those transactions that disrupt the markets would be punished. The direct result of this approach would

261. Goshen \& Parchomovsky, supra note 25, at 716 ("Restrictions on fraud and manipulation simultaneously lower information traders' cost of verifying the credibility of information and improve their ability to make accurate predictions.").

262. Yakov Amihud, Haim Mendelson \& Lasse Heje Pedersen, Liquidity and Asset Prices, 1 FOUND. \& TRENDS IN FIN. 269, 270 (2005) (explaining that exogenous transaction costs reduce the number of agents in the market, reducing market liquidity). 
be that traders would be likely to trust the pricing efficiency of the markets and would trade freely with their counterparties. This would result in reduced transaction costs, greater market liquidity, and enhanced market efficiency. Thus, this Article's approach would reduce transaction costs by improving the efficacy of private and government actions against open-market manipulation.

2. Market Certainty and Regulatory Flexibility. This Article's approach eliminates much of the confusion that surrounds the law of open-market manipulation. As discussed above, the current confusion in the law stems primarily from the use of intent as the sole basis for liability. Market actors are uncertain whether their conduct may be deemed manipulative based on the Commissions' indeterminate inference of manipulative intent. The harm-based approach proposed herein moves away from the ambiguous intent standard and clearly specifies grounds on which facially legitimate transactions may be assessed as manipulative. By grounding liability on the effect of the trader's conduct on the market, this Article's approach bases liability on the combination of intent and harmful conduct. This would clarify for traders when their conduct may be considered manipulative, thereby allowing them to tailor their transactions to avoid allegations of manipulation.

The harm-based approach would grant needed flexibility to regulators in combatting open-market manipulation. The approach does not limit open-market manipulation to specific trading strategies or conduct. Rather it accepts that the mechanisms by which traders may manipulate the markets are limitless. Lawmakers need access to wide-ranging theoretical and practical tools to effectively address open-market manipulation. The harm-based approach provides just that. Allowing allegations of open-market manipulation to be based on the market damage caused by trades enables lawmakers to address market activity that undermines the markets' functioning. This approach keeps the Commissions in alignment with their regulatory goals by providing them with the ability to enforce the antimanipulation laws, while preserving meaningful limitations on the scope of the Commissions' authority.

It is likely that the harm-based approach would also improve the Commissions' track record of enforcing open-market manipulation in the courts. As seen in the case studies in Part II.B, the courts often view allegations of open-market manipulation skeptically because of the singular focus on the trader's intent. The inclusion of harm in the legal 
theory of liability would likely allay courts' skepticism of open-market manipulation because this theory explains why seemingly legitimate transactions are nonetheless manipulative. The law of open-market manipulation, as a result, would be more consistent. With a firm foundation for liability, lawmakers would be better able to articulate and analyze the factors that are necessary to prove market harm. Thus, open-market manipulation law would develop coherently and enhance market participants' confidence in the law's capabilities.

3. Private-Party Engagement. This Article's approach engages market participants in all stages of the regulatory oversight of openmarket manipulation-deterrence, detection, and enforcement. First, this Article's proposed internal-guidelines requirement is a form of self-regulation that asks traders and market participants to establish the rules by which they will utilize certain trading strategies. Selfregulation is a useful tool that straddles the middle ground between top-down government regulation and the absence of regulation; selfregulation is particularly beneficial in complex systems like the financial markets. ${ }^{263}$ Additionally, involving market participants in their own regulation minimizes resistance and fosters greater adherence to self-imposed rules. ${ }^{264}$ By establishing internal guidelines as a prerequisite for engaging in certain types of trades, this Article's proposal enables traders to be part of the regulatory process. Importantly, the internal rules companies develop to guide their traders would be better tailored to the individual needs of each entity than any generally applicable prohibitions the Commissions could draft. This Article's proposal, therefore, is a nuanced approach to trading strategies that are both problematic and beneficial; it would grant private parties the flexibility to decide whether and under what circumstances they will utilize certain trading strategies. Indeed, a company may determine that the scrutiny that would result from employing these suspicious trading practices is not worth the cost and choose to prohibit them altogether. As a result, there may be fewer instances of these disruptive trades as traders decide to forego them. ${ }^{265}$

Second, through ex post disclosures, market actors would assist regulators in identifying manipulative conduct. Market manipulation is

263. See Fletcher, Benchmark Regulation, supra note 97, at 1967-69 (discussing the benefits of self-regulation).

264. Id.

265. Id. at 1968 ("Self-regulation may, therefore, go beyond legal standards and impose higher ethical standards that benefit the entire industry." (citation omitted)). 
notoriously difficult to detect, and open-market manipulation, based on facially legitimate trades, is even more so. Having disclosure requirements in place would help lawmakers identify harmful conduct in two separate but related ways. Most obviously, trading disclosures would limit the data the Commissions must review de novo to distinguish legitimate trades from manipulative ones. These disclosures would be a useful mechanism, bringing attention to potentially disruptive trades that may only have a veneer of legitimacy, thereby enabling the Commissions to address open-market manipulation promptly. Less obviously, the process of identifying potentially harmful transactions would be advantageous to lawmakers because it would force them to consider which trading practices are harmful and why. In developing disclosure guidelines, the Commissions would be required to do their own internal analysis of trading patterns that they believe are disruptive and signal to the markets that these trades will be met with additional scrutiny. This process of engaging with the markets would likely endow the Commissions with a greater understanding of certain trading strategies and with an awareness of other strategies, not on the Commissions' radar, that market participants find problematic.

Third and lastly, this Article's approach would engage market participants as private-party enforcers of anti-manipulation laws, thereby improving the likelihood that open-market manipulation will be punished. Anti-manipulation laws currently allow private parties to bring claims of market manipulation under both the Exchange Act and the CEA. Generally, the availability of private causes of action both increases compliance with the regulatory framework because of fear of private lawsuits and decreases government costs because private litigants shoulder some of the costs of enforcement. ${ }^{266}$ Private-party suits are an important tool in enforcing market discipline because they allow aggrieved counterparties to vindicate their rights without awaiting government intervention. ${ }^{267}$ This Article's proposal supplements the currently existing private rights of action, most notably by expanding the grounds available for private claims. To the

266. Meric Sar, A Regulatory Retreat: Energy Market Exemption from Private AntiManipulation Actions Under the Commodity Exchange Act, 22 FORDHAM J. CORP. \& FIN. L. 605, 635 (2017) ("[T]he most important benefits of the supplemental private right of action approach are (i) greater compliance with ... norms due to greater deterrence caused by the potential of private lawsuits, and (ii) lower costs for the agency due to the allocation of litigation costs between private claimants and the ... agency.").

267. Id. 
extent that traders are able to defend themselves against market manipulation, they are more likely to participate in the markets. Private causes of action also ensure that recourse is available even in instances of open-market manipulation that are too insignificant to warrant the full-scale efforts of agency litigation. Furthermore, recognizing harm to market integrity as an independent cause of action would free private plaintiffs from the strictures of proving price manipulation, as long as they are able to demonstrate that transactions were manipulative due to their unfairness.

\section{B. Drawbacks}

Despite the benefits of this Article's proposal, there are potential drawbacks to the adoption of a harm-based approach. This Section addresses four objections. First, is exclusive reliance on ex post enforcement effective in preventing open-market manipulation? Second, does the proposal increase the difficulty of proving openmarket manipulation? Third, is the proposal's reliance on selfregulation flawed? Fourth, will recognition of market integrity as a basis for liability increase litigation in a way that proves costly and ineffective?

1. Ex Post Regulation. This Article proposes identifying openmarket manipulation by assessing whether the trader's conduct harmed market efficiency, market integrity, or both. The proposed regulation of open-market manipulation, therefore, is primarily backward-looking, thereby requiring that harm occur before liability attaches. There are drawbacks to regulating ex post, but in the case of open-market manipulation, ex post regulation is the best course of action.

Financial regulation is rarely exclusively prescriptive or reactive; it is usually a mix of both because prescriptive regulation requires that enforcement be upheld, and reactive regulation requires, at a minimum, that broad-based rules alert the markets of potential liability. Nonetheless, one may classify regulatory frameworks as primarily ex ante and prescriptive or ex post and reactive, depending on the focus of regulations. Ex post regulations attempt to mitigate harm that has already occurred, rather than preventing the harm from occurring in the first place. ${ }^{268}$ In the financial markets, relying primarily

268. Iman Anabtawi \& Steven L. Schwarcz, Regulating Ex Post: How Law Can Address the Inevitability of Financial Failure, 92 TEX. L. REV. 75, 92-93 (2013) (explaining that the goal of ex 
on ex post regulations may have significant negative repercussions on the markets, particularly if manipulative conduct is not discovered, halted, and punished promptly.

Determining the optimal timing and focus of regulations is a complex task, but it turns on analysis of three essential considerations: information availability, effectiveness of sanctions, and administrative costs. ${ }^{269}$ First, with respect to information availability, if regulators have limited information about the conduct they are regulating or deterring, then legal intervention should be ex post. Regulators need information about the nature of the misconduct, the magnitude of the harm, the identity of the perpetrator, or some combination thereof in order to effectively regulate conduct ex ante. ${ }^{270}$ In the absence of such information, it is better to allow markets to operate freely and to allow regulatory intervention only once more accurate information is available. Second, the timing of regulation depends on the effectiveness of sanctions in deterring undesirable conduct. $^{271}$ Sanctions are efficacious in discouraging misconduct when they can approximate the type and scope of harm that results from the misconduct. ${ }^{272}$ As such, sanctions should be ex ante if they can target the harm and its expected magnitude before the conduct has occurred. On the other hand, regulation should be ex post if the misconduct and its magnitude are best evaluated afterward. Third, the administrative costs of regulatory intervention must be considered. Ex ante regulation is preferred if the costs of monitoring and policing are less than the costs of investigating and litigating misconduct. ${ }^{273}$

Because of the sensitivity of the markets to destabilizing shocks that have wide-reaching effects throughout the economy, it may be

ante regulations is the prevention of negative financial shocks, and that ex post laws aim to mitigate the harm of financial shocks once they have occurred); Donald C. Langevoort, Managing the "Expectations Gap" in Investor Protection: The SEC and the Post-Enron Reform Agenda, 48 VILL. L. REV. 1139, 1154 (2003) ("Expressing the duty [to disclose] simply anticipates that investors are often misled by the nondisclosure and suffer considerable harm. Thus [the duty to disclose] should be explicitly within the purview of the federal securities laws.").

269. See supra Part I (discussing existing regulations).

270. See Fletcher, Benchmark Regulation, supra note 97, at 1938 (discussing the type and form of information needed to effectively craft ex ante regulations); see also STEVEN SHAVELL, FOUNDATIONS OF ECONOMIC ANALYSIS OF LAW 572-75 (2004) (advising that the fundamental dimensions of legal intervention fall under three categories: timing, form, and the private or public nature of the enforcement).

271. Fletcher, Benchmark Regulation, supra note 97, at 1938.

272. Id.

273. Id. 
problematic to focus regulation on addressing impediments to market efficiency and integrity after harm has occurred. These concerns are valid, and considerations regarding the timing of financial regulation ought not be ignored; however, in the context of open-market manipulation, regulation will be most effective if implemented ex post.

Importantly, while open-market manipulation can and does harm the markets, the effects of these manipulative schemes are likely to be contained. Both naked and covered manipulation typically target a single asset, which makes systemic market destabilization unlikely. Neither form of open-market manipulation is prolonged in its duration, as manipulators typically focus their efforts in time periods as short as minutes. Covered manipulation directed at distorting a benchmark may be one of the most impactful open-manipulation schemes; however, even then, such schemes target a single benchmark on a specific day. ${ }^{274}$ Therefore, the likelihood that open-market manipulation will be a source of systemic risk is quite low. ${ }^{275}$

Furthermore, based on the factors for determining the timing of legal intervention, open-market manipulation falls squarely in the ex post category. The importance of market harm to the identification of open-market manipulation means that regulators do not have sufficient information before the trades are executed and the impact of the transactions on the markets is analyzed. Sanctions put in place to deter open-market manipulation, therefore, would have little or no impact because it is almost impossible to anticipate the scope and nature of the harm that will result from an open-market manipulation scheme. Also, the administrative costs of monitoring and policing for open-market manipulation likely outweigh those for investigating and litigating because open-market manipulation involves legitimate trades that are difficult to detect. Lastly, it is important to note that although this Article's proposal is primarily focused on ex post remediation, it has some prescriptive aspects aimed at easing the detection and

274. This is unlike benchmark manipulation, in which traders manipulate benchmarks for years by distorting the inputs over which they have control. Benchmark manipulation may be accomplished through trades, but it is more effective when the traders have control of the calculation of the benchmark and distort it from within. See generally id. (discussing benchmark manipulation).

275. John C. Coffee, Jr., Bail-Ins Versus Bail-Outs: Using Contingent Capital to Mitigate Systemic Risk 1 (Ctr. for Law and Econ. Studies, Working Paper No. 380, 2010) (noting that systemic risk describes the "localized economic shock [that has] worldwide repercussions because of the interconnections between financial institutions." (citing Steven L. Schwarcz, Systemic Risk, 97 GEO. L.J. 193, 204 (2008))). 
deterrence of open-market manipulation. ${ }^{276}$ This Article's proposal recognizes the importance of establishing mechanisms preemptively to facilitate better ex post enforcement. In this way, it would minimize the likelihood that open-market manipulation would go unchecked for an extended period, wreaking havoc on the markets, because of a merely reactive framework.

2. Difficulty of Proving Harm. The harm-based framework this Article proposes requires that plaintiffs demonstrate both manipulative intent and harm to the markets. This approach increases the evidentiary burden on the government and private parties, which may make it more difficult to allege open-market manipulation. Additionally, this Article's proposal incorporates price manipulationa notoriously difficult standard-as one of the means by which plaintiffs can demonstrate market harm. Thus, a legitimate question exists as to whether the proposed harm-based approach improves enforcement against open-market manipulation.

This Article's proposal brings open-market manipulation in line with other conduct and activity that is deemed manipulative. Definitions of market manipulation include both intent and harm, whether the allegations are based on fraud, misrepresentation, or fictional trading. The Commissions' current approach to open-market manipulation dispenses with harm and focuses solely on the intent of the trader. Thus, this Article's approach merely corrects the anomalous treatment of open-market manipulation and harmonizes it with other forms of market manipulation. Additionally, there should be little concern over the harm-based approach placing a heavier burden on the government. Claims of open-market manipulation rest on allegations that legitimate transactions should be the basis of liability. If the government wants to hold someone liable for legitimate transactions, it ought to be required to meet a higher burden than one fulfilled by circumstantial evidence of intent alone.

Further, it is important to note that the Commissions and private plaintiffs have not been particularly successful in their enforcement of open-market manipulation on the basis of intent alone. As discussed previously, courts have been skeptical of allegations for manipulation based on intent alone. As a result, some courts have either refused to find liability without a showing of "something more"277 or held

276. See supra Part IV.A (discussing the benefits of this Article's proposal).

277. ATSI Commc'ns, Inc. v. Shaar Fund, Ltd., 493 F.3d 87, 101 (2d Cir. 2007) ("To be 
defendants liable only if their trades entirely lacked an investment basis. ${ }^{278}$ The harm-based approach would allay the courts' concerns and provide the Commissions with a way to respond to courts' underlying inquiry: Why are these facially legitimate trades manipulative? Thus, this Article's proposed approach responds to courts' skepticism by showing how legitimate trades can be used to manipulate the markets via the resulting market injury. Harm offers the Commissions and the courts an objective and verifiable way to identify open-market manipulation that is less circumstantial than the previous intent-centric approach.

3. Self-Regulation. This Article's proposal relies on entities and traders adopting and enforcing internal guidelines for potentially manipulative trading strategies. Traders would also be expected to selfreport conduct that may subject them to enhanced scrutiny and, possibly, to enforcement actions. Including self-regulation as a key component of this Article's proposed framework raises important questions and concerns.

Self-regulation requires the government to trust market actors to participate in their regulation. Critics of self-regulation posit that "private profit-seeking enterprises cannot be trusted to regulate their own activities in a manner conducive to promotion of publicly desirable goals." ${ }^{279}$ This observation is all the more poignant given that traders would be expected to self-report conduct that may result in their own liability.

These concerns with respect to self-regulation should not be ignored, but they are not as significant within the context of this Article's proposal. This Article's proposal does not rest on selfregulation operating in a vacuum. Rather, self-regulation would be one of the tools available to regulators in detecting open-market manipulation. The government should also coordinate with exchange operators to detect trading activities that may have been unreported and to verify reports that have been made. Even in the absence of compliance and disclosure requirements, the Commissions are able to identify some instances of open-market manipulation. The inclusion of traders in their own regulation would only enhance the effectiveness of the process.

actionable as a manipulative act, short selling must be willfully combined with something more to create a false impression of how market participants value a security.").

278. See supra Part II.B (discussing SEC v. Masri, 523 F. Supp. $2 d 361$ (S.D.N.Y. 2007)).

279. Saule T. Omarova, Rethinking the Future of Self-Regulation in the Financial Industry, 35 BROOK. J. INT’L L. 665, 674 (2010). 
4. Increased Litigation. Lastly, one may also be concerned that this Article's advocacy for market integrity as an additional basis of liability would increase litigation for heretofore acceptable conduct. While this may occur, it is more likely that in the absence of a private cause of action for unfair market behavior, unlawful conduct escapes liability, to the detriment of market integrity and efficiency. The cost of increased litigation is less important when weighed against the benefit to the markets from allowing market actors to vindicate their rights. This is particularly true considering the possibility that market participants may still utilize contractual provisions to waive or enforce their right to engage in otherwise unfair market conduct. Therefore, any increase in private litigation may, in fact, increase market integrity and efficiency, and to the extent that traders want to avoid being held liable for unfairness, they may contractually opt out of that liability, as long as their counterparties agree.

\section{CONCLUSION}

Imposing liability for legitimate transactions raises knotty but important questions. The intent of the actor, however, is not a legally adequate or sound basis on which to ground liability. Within the current approach-one espoused by the Commissions, private plaintiffs, and some courts - intent plays an outsized role that does not increase market safety because it fails to accurately target open-market transactions that undermine the markets. This Article's proposal addresses this glaring shortcoming.

This Article's approach to open-market manipulation employs intent to ensure that traders are not liable for negligent or accidental trades that cause harm. This approach also includes harm in the analysis of open-market manipulation, adding needed clarity to this corner of the market. A harm-based analysis provides a coherent way to distinguish between legitimate transactions and manipulative conduct. This approach would assure market actors that their intent alone will not make them liable for manipulation, and it would appropriately target those transactions that impair the functioning of the market. Furthermore, by considering market harm in terms of market efficiency and integrity, this Article acknowledges a form of market injury that is more amorphous - unfairness - but nonetheless detrimental to the markets. The Commissions and the courts must amend their approach to open-market manipulation. Adopting a harm-based approach would provide a more complete basis on which 
to address this form of market manipulation, and it would ultimately improve the markets' efficiency and enhance public trust and confidence in the markets. 